UNIVERSIDADE DE SÃO PAULO

FACULDADE DE FILOSOFIA, LETRAS E CIÊNCIAS HUMANAS

DEPARTAMENTO DE FILOSOFIA

PROGRAMA DE PÓS-GRADUAÇÃO EM FILOSOFIA

\title{
CORPO, SAÚDE E MEDICINA \\ A PARTIR DA FILOSOFIA DE NIETZSCHE
}

Adriana Belmonte Moreira

Dissertação apresentada ao Programa de Pós-Graduação (Mestrado) em Filosofia, do Departamento de Filosofia da Faculdade de Filosofia, Letras e Ciências Humanas da Universidade de São Paulo.

Orientador: Profa. Dra. Scarlett Marton 
UNIVERSIDADE DE SÃO PAULO

FACULDADE DE FILOSOFIA, LETRAS E CIÊNCIAS HUMANAS

DEPARTAMENTO DE FILOSOFIA

PROGRAMA DE PÓS-GRADUAÇÃO EM FILOSOFIA

\section{CORPO, SAÚDE E MEDICINA \\ A PARTIR DA FILOSOFIA DE NIETZSCHE}

Adriana Belmonte Moreira

São Paulo

2006 
A saúde da alma - A apreciada fórmula de medicina moral (cujo autor é Ariston de Quios), ‘A virtude é a saúde da alma’ - deveria ser modificada, para se tornar utilizável, ao menos assim: 'Sua virtude é a saúde de sua alma’. Pois não existe uma saúde em si, e todas as tentativas de definir tal coisa fracassaram miseravelmente. Depende do seu objetivo, do seu horizonte, de suas forças, de seus impulsos, de seus erros e, sobretudo, dos ideais e fantasias de sua alma, determinar o que deve significar saúde também para seu corpo. Assim, há inúmeras saúdes no corpo: e quanto mais deixarmos que o indivíduo particular e incomparável erga sua cabeça, quanto mais esquecermos o dogma da 'igualdade dos homens', tanto mais nossos médicos terão de abandonar o conceito de uma saúde normal, juntamente com dieta normal e curso normal da doença. E apenas então chegaria o tempo de refletir sobre saúde e doença da alma, e de situar a característica virtude de cada um na saúde desta: que numa pessoa, é verdade, poderia parecer o contrário da saúde de uma outra. Enfim, permaneceria aberta a grande questão de saber se podemos prescindir da doença, até para o desenvolvimento de nossa virtude, e se a nossa avidez de conhecimento e autoconhecimento não necessitaria tanto da alma doente quanto da sadia; em suma, se a exclusiva vontade de saúde não seria um preconceito, uma covardia e talvez um quê de refinado barbarismo e retrocesso.

(NIETZSCHE) 
À Scarlett, pela orientação e incentivo, em prova de que uma relação filosófica não prescinde de afeto.

Aos colegas do GEN (Grupo de Estudos Nietzsche), que nos últimos anos compartilharam as minhas e as suas reflexões.

À minha família, irmãos e irmãs, cunhado e sobrinhos, e em especial à minha mãe, pelo apoio de uma vida.

Aos meus amigos, especialmente às minhas amigas de longa data, Marta, Rita, Christiane, Irinéia e Mônica.

Ao Eduardo, pela companhia amorosa e intenso diálogo. 


\section{SUMÁRIO:}

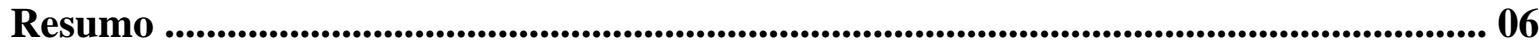

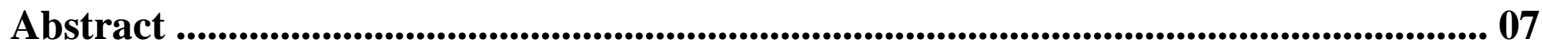

Notação Bibliográfica ............................................................................................................................ 08

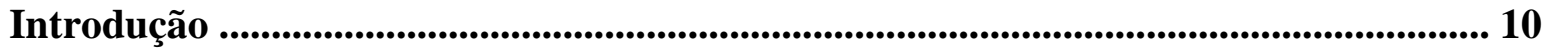

Capítulo I - Nietzsche e Descartes:

duas concepções de corpo em duelo e diálogo ...................................................................... 20

Capítulo II - O diagnóstico da grande saúde:

ensaio, experimentação e criação .................................................................................... 44

Capítulo III - A medicina filosófica:

uma tarefa para um tempo vindouro ...............................................................................................67

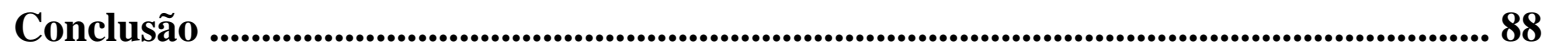

Bibliografia ......................................................................................................................................... 92 


\section{RESUMO:}

Em nossa dissertação, lançamos mão das concepções nietzschianas de corpo e de grande saúde como instrumentais para refletir sobre as atuais práticas médicas. Inicialmente, tendo em vista que Nietzsche procura fazer frente à metafísica através de sua concepção de corpo, procuramos colocá-la frente a frente com a concepção cartesiana. Mostramos que Nietzsche considera a distinção entre res cogitans e res extensa a versão mais arrematada da separação entre alma e corpo, o alicerce do modo de pensar metafísico. Em um segundo momento, apresentando o que o filósofo entende por grande saúde e décadence, examinamos de que maneira, ao tomar o corpo como a matriz dos sentidos e valores, ele faz de sua crítica genealógica uma diagnose tipológica. Fazemos ver, então, de que modo, através do ensaio, experimentação e criação, ele subverte a concepção corrente de saúde, chegando, em sua autodiagnose tipológica, a considerar-se um tipo saudável, malgrado seus constantes episódios de enfermidade. Por fim, realizamos uma reflexão sobre a atual concepção de saúde e sobre as práticas médicas que dela decorrem. Tendo por norte os critérios diagnósticos oferecidos pela filosofia nietzschiana, investigamos se através de nossas práticas de saúde não acabamos por promover a décadence.

PALAVRAS-CHAVE: corpo; grande saúde; décadence; criação; medicina. 


\section{ABSTRACT:}

In the present dissertation, we use the nitzschean concepts of body and great health as tools to reflect upon the current medical practices. Initially, keeping in mind what Nietzsche does for metaphysics, through his conception of the body, we intend to confront it with the Cartesian conception. We show that Nietzsche considers the distinction between res cogitans and res extensa, which is the most finished version of the soul and body separation, the foundation of the metaphysical way of thinking. Secondly, presenting what the philosopher understands by great health and decadence, we will examine the manner by which, in taking the body as the matrix for the senses and values, he makes of his genealogical criticism a typological diagnosis. We will then see, in what way, through the essay, experimentation and creation, he subverts the current conception of health and reaches his typological self-diagnosis, considering himself a healthy type, despite his constant sickness episodes. Finally, we will reflect upon the current conception of health and medical practices resulting from it. With the focus on the diagnosis criteria offered by the nietzschean philosophy, we will investigate whether through our health practices we don’t end up promoting the décadence.

KEYWORDS: body; great health; décadence; creation; medicine. 


\section{NOTAÇÃO BIBLIOGRÁFICA:}

Para as citações das obras de Nietzsche, adotamos a convenção proposta pela edição Colli/Montinari das Obras completas do filósofo. Para facilitar a leitura das referências, as siglas em alemão são acompanhadas das siglas em português:

MAI/HHI - Menschliches Allzumenschliches (Humano, demasiado humano vol I) - 1878 e 1886 (prefácio)

VM/OS - Menschliches Allzumenschliches: Vermischte Meinungen und Sprüche (Humano, demasiado humano vol II; Miscelânea de opiniões e sentenças) - 1879-1880 e 1886 (prefácio)

FW/GC - Die fröhliche Wissenschaft (A Gaia Ciência) - 1881-1882 e 1886 (prefácio e livro V)

Za/ZA - Also sprach Zarathustra (Assim falava Zaratustra) - 1883-1885

JGB/BM - Jenseits Von Gut und Böse (Para Além de Bem e Mal) - 1885-1886

GM/GM - Zur Genealogie der Moral (Genealogia da Moral) - 1887

WA/CW - Der Fall Wagner (O Caso Wagner) - 1888

GD/CI - Götzen- Dämmerung (Crepúsculo dos Ídolos) - 1888

AC/AC - Der Antichrist (O Anticristo) - 1888

EH/EH - Ecce Homo - 1888

Na citação, o algarismo arábico indicará o parágrafo (ex: AC/AC, 12). Na citação de GM/GM e de FW/GC, o algarismo romano anterior ao arábico remeterá à parte do livro (ex: GM/GM, II, 16). Em Za/ZA, o algarismo romano remeterá à parte do livro e a ele seguirá o título do discurso (ex: Za/ZA, I, Dos Ultramundanos). No caso de GD/CI e EH/EH, o algarismo arábico, que se seguirá ao título do capítulo, indicará o parágrafo (ex: GD/CI, A “razão” na filosofia, 1). 
Para as citações das obras de Descartes, optamos pela seguinte convenção: Para o Discurso do Método, após o título da obra, o algarismo romano indicará a parte do livro. Para Meditações e As paixões da Alma, o algarismo romano indicará a parte do livro e o arábico o parágrafo (ex: As Paixões da Alma, I, 06). Para Princípios de Filosofia, após o título da obra, os algarismos romanos indicarão, respectivamente, a parte da obra e o parágrafo da edição em latim (ex: Princípios de Filosofia, I, XXXII).

Para os textos de Nietzsche e Descartes, privilegiamos as traduções:

NIETZSCHE. Obras Incompletas (Trad: Rubens Rodrigues Torres Filho). OS PENSADORES. São Paulo, Ed. Nova Cultural, 1999.

DESCARTES. Obras Incompletas (Trad: J. Guinsburg e Bento Prado Júnior). OS PENSADORES. São Paulo, Victor Civita, 1973. 


\section{INTRODUÇÃO:}

É decisivo quanto ao destino do povo e da humanidade que se comece a cultura a partir do lugar correto - não a partir da "alma" (como era a superstição fatídica dos sacerdotes e semi-sacerdotes): o lugar correto é o corpo, os gestos, a dieta, a fisiologia, o resto segue daí...

(NIETZSCHE).

O que julgamos singular na filosofia de Nietzsche, é que, em relação a toda uma tradição filosófica que atribui ao espírito estatuto privilegiado, nela o corpo é considerado um problema filosófico de primeira ordem e colocado no centro de uma empreitada crítica. De modo mais preciso, se a matriz do pensamento ocidental separou o corpo do âmbito dos valores, o filósofo o coloca no centro de sua tarefa genealógica. Com efeito, ao se imbuir da tarefa de realizar o exame dos valores, detectando se são sintomas de grande saúde ou décadence dos tipos que os engendraram, ele passa a operar sua crítica através de uma diagnose tipológica. O critério que utiliza para realizar sua análise diagnóstica é a mobilização do corpo, em sua potencialidade para o ensaio, experimentação e criação de sentidos e valores. Em vista disso, acreditamos que a filosofia nietzschiana não somente pode nos ajudar a pensar outros pressupostos para nossas práticas de saúde, mas também refletir sobre os impasses éticos que ao redor delas gravitam.

Em nosso percurso, teremos por horizonte que nossa problemática se inscreve na crítica que Nietzsche faz à separação entre alma e corpo, que considera ser a matriz do modo de pensar metafísico. Se no parágrafo intitulado "História de um erro", o filósofo apresenta a divisão de mundos como a marca da tradição filosófica ocidental, é dessa primeira separação que ela decorre (Cf. GD/CI, Como o “verdadeiro mundo” acabou por se tornar em fábula). Com efeito, no Prólogo de Para Além de Bem e Mal, ele diz que para 
erguer o enorme edifício metafísico da modernidade bastou a superstição da alma, "que, como a superstição do sujeito e do Eu, ainda hoje causa danos” (JGB/BM, prólogo). Além disso, deixa entrever que, após sucessivos refinamentos, a alma platônica encontrou na res cogitans cartesiana sua versão mais rematada. Desta forma, entendemos que ao apresentar o corpo como multiplicidade de impulsos em luta e afirmar que até mesmo a alma é formada a partir da relação desses impulsos entre si (CF. GM/GM, II, 16), o filósofo procura minar o primeiro dualismo metafísico, a partir do qual todos os demais foram cunhados.

Sendo assim, ao remeter corpo e alma ao mesmo registro, o da multiplicidade de impulsos em combate, Nietzsche esboroa a separação entre os domínios fisiológico e psicológico e apresenta uma fisiopsicologia, na qual sua tarefa crítica se ancora. É a partir dela que, como psicólogo, ao perscrutar a relação entre saúde e filosofia, considera os pensamentos sintomas de determinados corpos, “de seu acerto ou desacerto, de sua plenitude, potencialidade, autodomínio na história, ou então de suas obstruções, cansaços, empobrecimentos, de seu pressentimento do fim, de sua vontade de fim” (FW/GC, Prefácio, 2). Como genealogista, ao ter em vista que toda tábua de valor, todo "tu deves” conhecido na história concerne à saúde do corpo, diz que é necessário fazer com que fisiólogos e médicos se interessem pelo problema do “valor das valorações” até agora existentes, tornando frutífera a relação entre fisiologia, filosofia e medicina, originalmente tão seca e desconfiada (Cf. GM/GM, I, 17).

Em nosso entender, se Nietzsche diz que é necessário aos médicos se interessar pelos valores é também porque toda criação pressupõe sofrimento e sofredores. Ele entende que toda filosofia é um meio de cura e auxílio a serviço de uma vida que combate. Por isso, ao direcionar seu olhar para os modos de pensar e valorar procura diagnosticar a necessidade que comanda por trás deles: "sirvo-me agora desta distinção capital: em cada caso, pergunto: ‘aqui foi a fome ou o supérfluo que se tornou criativo?’” (FW/GC, V, 370). No âmbito do procedimento genealógico, ao se perguntar pelo valor dos valores, 
investiga se a moral é uma influência fecunda ou um perigo, um veneno, um narcótico para o tipo (GM/GM prólogo, 6). Entrementes, conjetura sobre a significação do sofrimento para os tipos, se ele conduz à criação de ardis de autoconservação ou de sentidos e valores afirmativos dos processos efetivos. Em seus escritos de caráter autobiográfico, Nietzsche conta que até mesmo seus episódios de dor e enfermidade contribuíram para sua tarefa filosófica e, precisamente por isso, ao realizar sua autodiagnose tipológica, se considera um tipo saudável.

Na mesma via que trilhamos, Müller-Lauter, em A Doutrina da Vontade de Poder em Nietzsche ${ }^{1}$ defende que o filósofo recorre à multiplicidade para se contrapor ao pensamento metafísico. Em debate sobre a inscrição da filosofia nietzschiana na tradição metafísica, em claro diálogo com o pensamento heideggeriano, argumenta que para sermos justos com o pensamento de Nietzsche, primeiramente, é necessário aclarar qual é sua concepção de metafísica: “do pensar não-metafísico de Nietzsche, falo apenas quando apresento, de modo imanente, seu entendimento de metafísica” ${ }^{2}$. Por esse viés, acredita que, para o filósofo, o pensar metafísico se ancora na afirmação de uma unidade fundamental: "trata-se de metafísica quando 'é deduzida uma multiplicidade a partir de um primeiro simples "’3 . Destarte, conclui que é pelo viés da multiplicidade que ele se opõe à unidade, como um primeiro simples, defendida pela metafísica, pois, em sua filosofia: “não há o um, há apenas multiplicidades se reunindo, se separando”. Sendo assim, para Nietzsche, qualquer unidade somente poderá ser pensada no sentido de organização de um múltiplo. E, mais precisamente, como uma multiplicidade em combate, do qual decorrem múltiplas formações de domínio (Herrschafts-Gebilde). Portanto, conclui Müller-Lauter, é

\footnotetext{
${ }^{1}$ MÜLlER-LAUTER, W. A Doutrina da Vontade de Poder em Nietzsche (Trad. Oswaldo Giacóia Júnior). São Paulo, Annablume, 1997.

${ }^{2}$ Cf. MÜLLER-LAUTER, W. Op Cit (p.72)

${ }^{3}$ Ibidem (p.71-72)
} 
por não advogar uma unidade fundamental que o filósofo alemão consegue se afastar da tradição metafísica.

Para o comentador, na filosofia nietzschiana, do singular somos sempre remetidos ao plural. É por esse prisma que Nietzsche apresenta o corpo como uma configuração (Gestalttungen), um ajustamento hierarquicamente estruturado de uma multiplicidade em combate. Por certo, uma configuração instável, visto que no combate os beligerantes perfazem incessantemente outras relações de domínio. E, desse processo, nem mesmo a consciência pode furtar-se. Para o filósofo, parafraseia Müller-Lauter, somos uma multiplicidade que se imaginou uma unidade: “a consciência, o intelecto, serve como meio

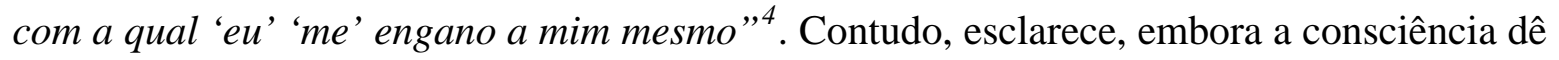
a entender para si mesma uma unidade, não há nenhum individuum. A unidade é somente o resultado de sua atividade simplificadora que, chancelada pelos preconceitos da metafísica da linguagem, toma o complexo pelo simples, o diverso pelo igual, o múltiplo pelo uno. Nesse sentido, o Eu da linguagem é apenas uma unidade simulada pela consciência. No limite, o que faz com que o tomemos por um substrato é um falseamento operado pela consciência e consolidado pela linguagem comum.

Com efeito, para Nietzsche, o Eu pensante cartesiano, tomado erroneamente por unidade, é, ao fim das contas, uma multiplicidade em combate. Sob sua óptica, atributos como substancialidade, unidade, identidade, eternidade, longe de remeterem a um sujeito, a uma res cogitans, encontram assento apenas na atividade simplificadora da consciência, que norteia as pressuposições fundamentais da metafísica da linguagem (Cf. GD/CI, A “razão” na filosofia, 5). Por isso, para se contrapor ao pensamento metafísico, além de remeter corpo e alma a uma multiplicidade de impulsos em luta, o filósofo alemão também realiza sua crítica através de uma análise da linguagem. Através de seu instrumental diagnóstico, ele detecta que a univocidade do conceito, própria à metafísica, é sintoma de

\footnotetext{
${ }^{4} \operatorname{Idem}(\mathrm{p} .79)$
} 
décadence. Assim sendo, em oposição ao conceito que fixa, demarca, petrifica, procura retornar a linguagem à natureza mesma da imagem, de modo a expressar o inaudito através do mais imediato, do mais cotidiano (Cf. EH/EH, Assim falava Zaratustra, 6). A partir disso, esclarece que se pode inovar na arte do discurso é porque seu "pressuposto fisiológico” o faz um tipo da grande saúde (Cf. EH/EH, Assim falava Zaratustra, 2). Destarte, como veremos, é, sobretudo, através de imagens que o filósofo procura expor suas idéias.

Nessa direção, Blondel, em Nietzsche, le corps et la culture ${ }^{5}$, se atém em investigar as estratégias nietzschianas para a superação da linguagem metafísica. Ele defende que o filósofo lança mão das metáforas, pois acredita que o discurso lógico-metafísico pautado na univocidade e fixidez da relação entre significante e significado, no convencionalismo dos códigos da linguagem, aparece como o resultado da negação da vida, da história, do corpo. A seu ver, Nietzsche, questionando a capacidade do discurso filosófico de enunciar a linguagem não discursiva do corpo, considera ser a metáfora o que "permite pensar a unidade plural do sensível e do inteligível, do corpo e do espírito para dizer a vida”6. Assim, seu discurso é metafórico porque procura escapar das limitações da linguagem conceitual, que simplifica e esquematiza. Em vista disso, o comentador conclui que a pluralização da relação entre significante e significado melhor expressa o corpo porque ele é uma unidade plural: "o retorno nietzschiano ao corpo é um retorno para o plural dos impulsos [Triebe]". ${ }^{7}$ Além disso, partindo da consideração de que "escrever, falar, para Nietzsche, não devem ser distinguidos das atividades fisiológicas”8, salienta que através do texto e pelo discurso sempre quem diz é o corpo. Desta forma, o texto não se resume a elementos lógico-conceituais, mas, mais do que isso, sempre nos remete ao elemento

${ }^{5}$ BLONDEL, É. Nietzsche, le corps et la culture: la philosophie comme généalogie philologique. Philosophie d'aujourd' hui, Presses Universitaires de France, 1986.

${ }^{6}$ Cf. BLONDEL. E. Op Cit (p.36)

${ }^{7}$ Ibidem (p.238)

${ }^{8}$ Idem (p.51) 
extradiscursivo: o plano dos impulsos ["plan des affects”]. Nessa direção, a filologia de Nietzsche, ao voltar-se do texto para o plano dos impulsos, é identificada à tarefa genealógica: "[o método] primeiramente, denominado filológico, como tal, pode ser

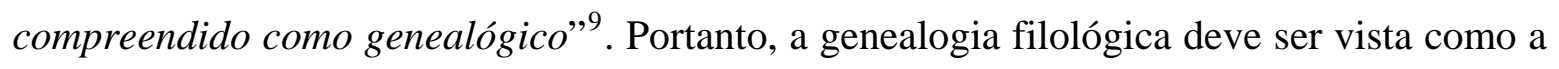
leitura e a escuta do corpo através do texto e do discurso.

Com efeito, no âmbito do procedimento genealógico, Nietzsche diz que é necessário remeter os valores às condições e circunstâncias nas quais nasceram. Com isso, quer dizer que não basta localizar historicamente a emergência de uma valoração, é necessário ainda considerá-la sintoma e remédio para o tipo que a engendrou (Cf. GM/GM, Prólogo, 6). É nesse sentido que podemos dizer que a genealogia nietzschiana incorpora a história e a fisiologia. Afinal, vemos, por diversas vezes, o filósofo recorrer a essas disciplinas para se contrapor à metafísica. Ele denuncia que é por falta de sentido histórico que os metafísicos desconsideram a mudança e transformam as coisas em sub specie aeterni (Cf. GD/CI, A “razão” na filosofia, 1), que é por ignorarem a fisiologia que acreditam em uma alma imortal, em uma consciência sempre idêntica a si mesma. Assim, através do recurso à história, ele quer ressaltar o caráter processual da efetividade e, a partir de sua fisiologia, “mortalizar” a alma.

Foucault, em Nietzsche, a genealogia e a história ${ }^{10}$, apresenta o uso que o filósofo faz da fisiologia e da história no interior da genealogia, como estratégia para se afastar da metafísica. A seu ver, para Nietzsche, o genealogista "necessita da história para conjurar a quimera da origem, um pouco como o bom filósofo necessita do médico para conjurar a sombra da alma”"11. Ora, na filosofia nietzschiana, a história não se identifica à pesquisa da origem (Ursprung): “a origem está sempre antes da queda, antes do corpo, antes do

\footnotetext{
${ }^{9}$ Idem (p.52)

${ }^{10}$ FOUCAULT, M. Nietzsche, a genealogia e a história In: Microfísica do poder (Trad: Roberto Machado). Rio de janeiro, Edições Graal, 1979.

${ }^{11}$ Cf. FOUCAULT. M. Op Cit (p.19)
} 
mundo e do tempo"12. Todas as coisas não tiveram um início perfeito, nem saíram das mãos do criador. É, pois, à tradição metafísica que cabe a pesquisa da origem, a busca pelo “fundamento originário”. Em direção contrária, o genealogista direciona seu olhar para o que está mais próximo, para aquilo que era tido como não possuindo história: o corpo, os sentimentos, a consciência, os instintos. Assim, de acordo com Foucault, em Nietzsche, o sentido histórico está muito mais próximo da medicina do que da filosofia, que sempre operou a partir da negação sistemática do corpo. Não é, portanto, na idealidade longínqua da origem ou na quimera da alma que reside o discurso filosófico, mas no corpo, em suas intensidades e desfalecimentos, agitações e furores secretos, por isso "é preciso saber diagnosticar as doenças do corpo, os estados de fraqueza e de energia, suas rachaduras e suas resistências para avaliar o que é um discurso filosófico"13.

É, pois, ao inscrever o corpo na história que o filósofo nos faz ver que ele não está reduzido à constância das leis fisiológicas, não se encontra imune à imprevisibilidade dos acontecimentos efetivos: "pensamos em todo caso que o corpo tem apenas as leis de sua fisiologia, e que ele escapa à história. Novo erro; ele é formado por uma série de regimes que o constroem, ele é destroçado por ritmos de trabalho, repouso e festa; ele é intoxicado por venenos - alimentos ou valores, hábitos alimentares e leis morais simultaneamente; ele cria resistências” ${ }^{14}$. Destarte, o olhar do genealogista deve ser semelhante ao do médico. Deve voltar-se para o corpo, para o sistema nervoso, aos alimentos, à digestão, às energias, perscrutar as decadências. Ele deve dominar a "ciência dos remédios”. O comentador entende que é assim que Nietzsche consegue questionar a afirmação de verdades eternas, de uma alma imortal, de uma consciência sempre idêntica a si mesma, e encontrar na idiossincrasia mesma de um filósofo a negação do corpo, seu ódio contra o devir, seu “egiptismo”.

\footnotetext{
${ }^{12}$ Ibidem (p.18)

${ }^{13}$ Idem (p.19)

${ }^{14}$ Idem (p.27)
} 
Também acreditamos que o genealogista direciona seu olhar para a forma como o tipo escolhe seus modos de vida, estabelece seus ritmos, elabora sua dieta. Mas, de modo mais preciso, entendemos que são os sentidos e valores, orientadores dos modos de vida, o que o filósofo toma por sintomas para compor sua tipologia. Entendemos que, para fazer sua análise diagnóstica, Nietzsche elege por critérios o ensaio de ordenações hierárquicas de impulsos, a experimentação de diferentes modos de querer, sentir e pensar, que culmina na criação de sentido e valor. De acordo com ele, todo sentido emerge das relações estabelecidas entre impulsos e é unicamente desse conflito que os valores advém: "Se falamos de valores, falamos sob a inspiração, sob a óptica da vida: a vida mesma nos coage a instituir valores, a vida mesma valora através de nós, quando instituímos valores” (GD/CI, Moral como contranatureza, 5). Com isso, ele se recusa a deslocar o sentido da existência para um além-mundo (Cf. GM/GM, III, 28) e nega a origem transcendente dos valores (Cf. ZA/Za. Dois mil e um alvos). Assim, esclarece que a sede dos sentidos e valores é a própria vida, agora não mais entendida em oposição à morte, mas identificada às múltiplas interações estabelecidas entre impulsos.

Deleuze, em Nietzsche et la Philosophie ${ }^{15}$, afirma que a tipologia é a "peça mestra” da genealogia nietzschiana. Ele acredita que através dela Nietzsche radicaliza sua crítica genealógica. Concordamos com sua leitura, ao afirmar que o filósofo, ao articular genealogia, sintomatologia e tipologia, recrudesce sua crítica. Para o comentador, a genealogia é a verdadeira forma de filosofar a golpes de martelo: "A filosofia dos valores, tal como ele a instaura e a concebe, é a verdadeira realização da crítica, a única maneira de realizar a crítica total, quer dizer, de fazer a filosofia a 'golpes de martelo'” (DELEUZE, 1970, p.01). A seu ver, o filósofo alemão, ao apresentar como seu problema crítico o valor dos valores, coloca em questão a avaliação donde procede o valor, ou seja, o problema de sua criação. Por esse viés, todos os valores são considerados sintomas de

\footnotetext{
${ }^{15}$ DELEUZE, G. Nietzsche et la Philosophie. Paris, Presses Universitaires de France, 1970.
} 
maneiras de ser, dos modos de existência daqueles que avaliam: “É porque temos sempre as crenças, os sentimentos, os pensamentos que nós merecemos em função de nossa maneira de ser e de nosso estilo de vida” (DELEUZE, 1970, p.02). Em vista dessa análise deleuziana, fortalecemos nossa posição de que é pela vereda da genealogia, da sintomatologia e da tipologia que as concepções nietzschianas de grande saúde e décadence podem ser investigadas.

Ademais, o comentador defende que Nietzsche introduz na filosofia os conceitos de sentido e valor. Esclarece que enquanto o sentido emerge da relação (rapport) entre as coisas, o valor concerne à hierarquia (hiérarchie) que nelas se exprime. Entrementes, destaca o problema do “sentido do sofrimento”, se ele conduz a uma condenação ou a uma afirmação da existência em sua integralidade. Em nosso trabalho, veremos que Nietzsche, em sua tipologia, também considera ser sintoma de grande saúde ou décadence o sentido que o tipo atribui a seu sofrimento. Sobretudo em seus escritos de caráter retrospectivo, o filósofo apresenta a significação singular que atribui a seus episódios de enfermidade. Afirma que serviram à criação de sentidos e valores afirmativos (Cf. EH/EH, Assim falava Zaratustra, 8). Precisamente por isso, ao realizar sua autodiagnose, se considera dotado de grande saúde.

Pelo propósito de nossa investigação, considerando a periodização mais usual da filosofia de Nietzsche, nos debruçamos no conjunto dos escritos da última fase (18831888), pois é nesse período que o filósofo aclara a relação entre corpo e valor, opera a crítica genealógica através dos diagnósticos da grande saúde e da décadence, e elabora seus escritos de caráter retrospectivo, em particular, os prefácios de 1886 e sua autobiografia Ecce Homo. Em nossa trajetória, no primeiro capítulo, realizaremos um embate entre as concepções de corpo nietzschiana e cartesiana, de modo a divisar algumas estratégias de Nietzsche para desfazer a separação entre corpo e alma, defendida pela tradição filosófica, bem como os demais dualismos que daí decorrem, como fisiologia e psicologia, vida e 
morte e, a divisão de mundos advogada pelos metafísicos. No segundo capítulo, apresentaremos o que Nietzsche entende por grande saúde e décadence. Pelo viés da genealogia, sintomatologia e tipologia veremos como o filósofo lança mão de sua concepção de corpo em sua empreitada crítica, vinculando a saúde à possibilidade de criação de sentidos e valores. No terceiro capítulo, recorreremos à figura do "médico filosófico”, como imagem daquele que se interessa pelo problema da saúde, para retomarmos os aspectos apresentados nos capítulos anteriores e fazermos uma reflexão sobre as práticas médicas na atualidade. 


\section{CAPÍTULO I:}

\section{Nietzsche e Descartes: duas concepções de corpo em duelo e diálogo}

Há mais razão no teu corpo do que na tua melhor sabedoria. E por que o teu corpo, então, precisaria logo da tua melhor sabedoria?

(NIETZSCHE)

No embate entre duas matrizes teóricas distintas, se na filosofia de Descartes é possível discernir com clareza uma definição de corpo, conceitualizá-lo, na filosofia nietzschiana, divisar uma concepção de corpo significa necessariamente extrapolar os limites de uma circunscrição conceitual, dada através de uma definição formal. Na Genealogia da Moral, Nietzsche afirma que se toda uma multiplicidade de sentidos é condensada, sintetizada em um único conceito, isso lhe subtrai qualquer definição; “todos os conceitos, nos quais coligem semioticamente um processo inteiro, esquivam-se à definição: definível é somente aquilo que não tem história” (GM/GM, II, 13). Ora, apresentar uma definição de corpo que servisse ao engessamento de um conceito seria perder de vista que a tarefa do filósofo é, sobretudo, desvelar o sentido de uma trajetória na qual um outro, a alma, ganhou proeminência às expensas do corpóreo. Em outros termos, seu intento é desmascarar o que se esconde por trás das tentativas de definição de corpo na tradição filosófica, perscrutar os sentidos do desprezo a tudo que lhe é próprio. Destarte, desvelar o “processo inteiro” que subjaz a uma definição de corpo significa não apenas colocar à mostra qual definição vigora desde a modernidade, mas o por quê ela foi assim firmada.

É, pois, para além de um engessamento conceitual que a concepção nietzschiana de corpo pode ser apresentada. Com efeito, no Crepúsculo dos ídolos, ao revelar a falta de sentido histórico como a idiossincrasia dos filósofos, Nietzsche assevera que nada de 
efetivamente vital veio das mãos de filósofos “idólatras de conceitos”, pois tiveram em mãos apenas “múmias conceituais”: “eles matam, eles empalham, quando adoram, esses senhores idólatras de conceitos” (GD/CI, A “razão” na filosofia, 1). De modo adverso, para o filósofo alemão, o corpo se furta ao egiptismo filosófico e não se deixa capturar nas malhas da aeterna veritas. Malgrado isso, mas não sem problemas, os “idólatras de conceitos” se obstinam em uma definição de corpo. No entanto, sede das diferenças, o corpo não exibe igualdades; de modo espantoso, produz efeitos inesperados diante das mesmas causas; impertinente, está suscetível a toda sorte de acidentes. O corpo se opõe à unidade, identidade, perenidade, indivisibilidade, na medida em que expõe processos de geração, crescimento, mudança, perecimento e morte. Assim sendo, se os “idólatras de conceitos” têm por tarefa encontrar uma verdade sobre o corpo, de modo a capturá-lo nos impermeáveis contornos de uma definição, necessariamente, essa captura dar-se-á in abstracto. Além disso, ironicamente, o que Nietzsche procurará desvelar é que por trás desta tarefa se oculta algo que os "idólatras de conceitos" se recusariam, de modo peremptório, a acreditar: é a própria inexorabilidade dos processos dinâmicos do corpo o que lhes impõe a busca incessante de uma definição de corpo, o que os impele à tentativa de sua captura em um conceito unívoco.

Logo, nos escritos nietzschianos, a concepção de corpo deve se inscrever em outra perspectiva. A nosso ver, Nietzsche não intenciona colocar mais uma estrela no céu dos conceitos da tradição filosófica; ele apresenta sua concepção de corpo, em consonância a um filosofar antimetafísico par excellence, que reabilita a mudança, a multiplicidade, a transitoriedade e o perecimento. Mais do que isso, procura também revelar que são os processos dinâmicos da efetividade a condição mesma do filosofar. Destarte, contra os “idólatras de conceitos” que procuram se afastar veementemente do dinamismo do corpo e seus testemunhos, na contramão daqueles que não são de seu feitio, mas nem por isso 
deixaram de receber destaque na tradição filosófica, Nietzsche declara guerra e indica os termos do combate:

A força do agressor tem na oposição de que precisa uma espécie de medida; todo crescimento se revela na procura de um poderoso adversário - ou problema: pois um filósofo guerreiro provoca também os problemas ao duelo. A tarefa não consiste em subjugar quaisquer resistências, mas sim aquelas contra as quais há que investir toda a força, a agilidade, a maestria das armas - subjugar adversários iguais a nós... Igualdade frente ao inimigo - primeiro pressuposto para um duelo honesto (EH/EH, Por que sou tão sábio, 7).

Desta vista, é de modo combativo e inter pares que ele coloca em campo o problema corpo. Além disso, para a garantia de um duelo honesto, ao expor seus princípios, esclarece que ataca unicamente “causas vitoriosas” e se investe contra pessoas é somente como "lente de aumento” para divisar um estado geral.

É sob essa perspectiva que, ao ver do filósofo alemão, a concepção cartesiana de corpo figura na história da filosofia de modo exemplar. Descartes levou a termo a separação entre corpo e alma, germinada na tradição socrático-platônica, ao coroá-la com a distinção substancial entre res extensa e res cogitans. Ao atribuir ao cogito o estatuto de primeira certeza ontológica, consolidou a primazia da alma, em detrimento ao corpo. Portanto, se Descartes afirma, nas Meditações, a certeza de sua essência pensante, inextensa, substancialmente distinta do corpo, Nietzsche protesta: Descartes, pai do racionalismo, “reconheceu autoridade apenas à razão: mas a razão não passa de instrumento, e Descartes era superficial” (JGB/BM, 191). De igual modo, em Assim falava Zaratustra, quando direciona sua palavra aos “desprezadores do corpo", ouvem-se novamente ecos da superficialidade cartesiana: 
Todo eu sou corpo e nada mais; a alma não é mais que uma palavra que designa uma parte do corpo (...) Essa pequena razão que tu chamas de "espírito”, ó meu irmão, é um pequeno instrumento do teu corpo e um brinquedo da tua grande razão (Za/ZA, I, Dos desprezadores do corpo).

É, pois, de modo estratégico, que o filósofo procurará subtrair a fachada da "pequena razão” cartesiana, apresentando sua proveniência no ordinário terreno da gregariedade e dando a conhecer seu caráter meramente instrumental. E se assim o faz é porque toma partido de uma "grande razão", que abarca a "pequena razão" e a restitui ao corpóreo.

Assim, nesse duelo e diálogo, cada qual por um viés, Nietzsche e Descartes apresentam suas concepções de corpo e os processos que lhes são próprios. Se Descartes apresenta o corpo em analogia a um relógio, ou outro autômato que se move por si mesmo (Cf. As Paixões da Alma. I, 06; 16), em manifesto embate, Nietzsche dispara; “o corpo é uma grande razão, uma multiplicidade com um único sentido, uma guerra e uma paz, um rebanho e um pastor" (Za/ZA, I, Dos desprezadores do corpo). Se o filósofo francês apresenta uma fisiologia que procura aclarar o funcionamento de um corpo-máquina, um corpo inteligível em seus mínimos processos e conjugado a uma alma com a qual, substancialmente, não irá se identificar, de modo antagônico, o filósofo alemão escolhe a multiplicidade, o combate, as relações de mando e obediência e lança mão do dinamismo de impulsos para expressar a fisiopsicologia de sua "grande razão", da qual a "pequena razão” será apenas brinquedo e instrumento.

Filiar-se a um adversário para potencializar uma crítica, mesmo que, em outro momento, passe a lhe desferir golpes, é estratégia comum a Nietzsche. É sob essa perspectiva que, em $O$ Anticristo, apesar de adversário declarado de Descartes, ele apresenta de forma inusitada, mas não sem propósito, um elogio ao filósofo francês: "No que se refere aos animais, Descartes foi o primeiro, com audácia digna de respeito, a ousar 
considerar o animal como machina: toda nossa fisiologia se esforça para demonstrar essa tese” (AC/AC, 14). Nessa passagem, deixa entrever que a tese do animal machina confirma, de algum modo, suas posições. Com efeito, de acordo com elas, o homem e os animais encontram-se lado a lado em “idêntico grau de perfeição” (AC/AC, 14). Ora, é certo que a tese cartesiana, na qual os corpos do homem e do animal são apresentados segundo um único modelo maquinal, corrobora essa posição. E é, pois, nesse aspecto que, para o filósofo alemão, a ousadia de Descartes é digna de respeito. Entretanto, é somente nesse ponto que procura pôr em relevo o caráter sui generis do animal machina cartesiano. Mais adiante, o elogio se transforma em crítica e Nietzsche traz a público o equívoco do filósofo francês:

Nós mudamos de método. Nós voltamos mais modestos em tudo. Não fazemos mais o homem derivar do espírito, da divindade, o colocamos entre os animais (...). Logicamente, não colocamos o homem à parte, como fazia Descartes: o que hoje se concebe do homem chega exatamente ao ponto em que foi entendido como uma máquina (...) Em outro tempo, via-se na consciência do homem, no “espírito”, a prova de sua procedência superior, de sua divindade; para aperfeiçoar o homem foi-lhe aconselhado, ao modo da tartaruga, concentrar seus sentidos em si mesmo, interromper o trato com as coisas terrenas, despojar-se do “invólucro mortal”: então restava o principal dele, o “espírito puro”. Nisso também modificamos nosso modo de pensar (...). O “espírito puro” é uma pura estupidez: descontando o sistema nervoso e os sentidos, o “invólucro mortal”, nos equivocamos em nossa conta - nada mais!... (AC/AC, 14).

Assim, se de início advogava filiação à tese cartesiana, agora, procura explicitar o ponto de divergência. Em clara referência ao método cartesiano, ele denuncia que Descartes, quiçá por imodéstia, ao recusar-se a colocar o homem dentre os animais, procurou isolar dos processos corpóreos um “espírito puro”, como testemunho de procedência divina. Não 
obstante, a seu ver, se a concepção cartesiana de homem tivesse ficado restrita a um corpo machina, poderia ter prescindido da "estupidez” do "espírito puro”. E, ao fim das contas, de modo perspicaz, insinua que foi o próprio Descartes quem deixou isso claro.

De fato, sabemos que Descartes abriu mão do espírito, ao apresentar sua concepção de corpo. De modo reiterado, o filósofo argumenta que o corpo do homem segue o modelo de uma máquina que pode executar suas ações unicamente porque suas partes encontram-se corretamente dispostas para seu funcionamento ${ }^{16}$. Todavia, para ele, o homem não pode ser identificado, como os animais, a um corpo máquina, mas a um “único todo” composto de corpo e alma. Desse modo, apesar da compleição e ações do corpo prescindirem do espírito, não deixa de afirmar quão enleados se encontram corpo e alma na natureza humana. Por outra perspectiva, nas Meditações, Descartes afirma que a alma, ou res cogitans, não está alojada no corpo, como um piloto em seu navio, mas está a ele misturada a todas as suas partes, sem, no entanto, confundir-se com res extensa. No entanto, se res extensa e res cogitans, embora realmente distintas (Cf. Princípios, I, LX; Meditações, VI, 17, 24) encontram-se completamente conjugadas no homem, resta ao filósofo demonstrar como podem compor um "único todo” ainda que, metafisicamente, a distinção possa ser concebida como real.

Assim, se, nas Meditações, Descartes apresenta a fundamentação metafísica da distinção substancial, em As Paixões da Alma, procura tratar mais detidamente de como

\footnotetext{
${ }^{16}$ No Tratado do Homem (1632), Descartes apresenta o corpo humano a partir do modelo de uma máquina, que executa suas funções unicamente pela disposição de suas partes como "os relógios, as fontes artificiais, os moinhos e outras máquinas semelhantes” (Tratado do Homem, p.140). Em As Paixões da Alma, obra redigida durante o inverno de 1645-1646, mas publicada somente algumas semanas antes de sua morte, em novembro de 1649, o filósofo retoma o mesmo modelo e procura novamente explicar "a forma toda de que se compõe a máquina de nosso corpo" (As Paixões da Alma, I, 7). Cf: MARQUES, J. Descartes e sua concepção de homem [com uma tradução do Tratado do Homem]. São Paulo, Edições Loyola, 1993 (Coleção Filosofia; v.25).
} 
corpo e alma podem sofrer um a ação do outro ${ }^{17}$. Estrategicamente, nessa obra, intenciona elucidar como as paixões da alma ou “as percepções, ou sentimentos, ou emoções da alma” (As Paixões da Alma, I, 27) podem ser causadas, mantidas ou fortalecidas pelos processos corpóreos. Para tanto, o filósofo parte da diferenciação entre alma e corpo, a partir da demarcação de suas funções particulares ${ }^{18}$, para, em seguida, discorrer sobre a

${ }^{17}$ A partir da apresentação da distinção substancial, a questão que se coloca é como se processaria a interação entre as duas substâncias, ou como a alma (imaterial) poderia exercer ações sobre o corpo (material), e também o contrário, quando as leis do movimento e do choque exigem contato entre corpos.

${ }^{18}$ Segundo Descartes, em As Paixões da Alma, a regra para o discernimento das funções do corpo e da alma deve partir da observação dos corpos inanimados. Destarte, tudo aquilo que é passível de ser atribuído a nosso corpo e a um corpo inanimado não deve ser concebido como pertencente à alma (Cf. As Paixões da Alma. I, 03). Se os corpos inanimados realizam movimentos e possuem tanto ou mais calor que os corpos dotados de alma, pode-se concluir que ao corpo pertence todo movimento e calor. Por não concebermos que os corpos pensem de alguma forma, os pensamentos pertencem tão somente à alma (Cf. As Paixões da Alma. I, 04). Assim, dotado de movimento e calor, o corpo encerra seus processos fisiológicos nos movimentos de pequenos corpúsculos, os “espíritos animais”. Descartes explica o que entende por espíritos animais; "o que denomino aqui espíritos não são mais do que corpos e não tem qualquer outra propriedade, exceto a de serem corpos muito pequenos e se moverem muito depressa (...)” (As Paixões da Alma. I, 10). Ainda, o filósofo define o calor cardíaco como princípio de todos os movimentos, pois os corpúsculos atuariam em estreita relação com a operação mecânica da dilatação cardíaca. Desse modo, ele dá uma atenção especial ao funcionamento do coração e à circulação sangüínea e à maneira através da qual os espíritos animais são distribuídos pelo corpo, desencadeando as ações musculares. Mais explicitamente, para Descartes, o coração apresenta um calor contínuo, uma "espécie de fogo”, gerador dos processos mecânicos de dilatação das cavidades cardíacas, e é o princípio corporal de todos os movimentos. O sangue transporta os espíritos animais do coração ao cérebro. Estes corpúsculos, por serem as partes mais sutis do sangue, atravessam os poros da glândula pineal e adentram a concavidade cerebral. Do cérebro, os corpúsculos migram à periferia do corpo, através dos nervos, um conjunto de pequenos tubos que estabelecem a conexão do cérebro com a periferia, e desencadeiam, assim, as ações musculares. Isso significa dizer que não existe um princípio, para além da estrutura corpórea, que anime o corpo para suas ações. Somente a agitação de tais corpúsculos e a diversidade de suas partes, "mais grossas ou mais agitadas" (As Paixões da Alma. I, 14), elucidam como ocorrem os movimentos musculares e, também, a operação dos sentidos. Assim, nos homens e, também, nos animais, todo movimento e calor são remetidos unicamente à compleição e à fisiologia corpórea. Isso significa dizer que é possível explicar a mecânica do corpo humano e do animal de modo similar, completamente a partir da extensão e das leis mecânicas do movimento dos corpos. 
interação. Entrementes, novamente às voltas com a distinção substancial, para equacionar este problema deveras espinhoso, encontra uma saída singular: indicar um ponto de contato entre a alma e o corpo e, assim, determinar na extensão um locus para o inextenso ${ }^{19}$ (Cf. As Paixões da Alma, I, 31,32).

Portanto, se, para Nietzsche, a concepção cartesiana do animal machina possibilita o esboroamento da distinção entre homem e animal é porque, também como res extensa, o homem compartilha com os demais animais o mesmo modelo explicativo para seus processos corpóreos. E é nesse aspecto que Descartes, para o filósofo alemão, foi audaz. Todavia, o filósofo francês se equivocou, ao tentar conferir ao homem um "espírito puro", como elemento diferencial que o colocaria à parte dos demais animais. Com efeito, para Nietzsche, se Descartes tivesse se contentado apenas com o corpo máquina, talvez tivesse se saído melhor, pois, como vimos, a tese do "espírito puro" não se encontra isenta de problemas $^{20}$.

${ }^{19}$ Descartes reconhece que a glândula pineal é a sede da alma, ou a parte do corpo em que ela exerce suas funções mais diretamente. Esta pequena glândula, localizada no centro do cérebro, é impulsionada, tanto pela agitação dos espíritos animais como pela ação da alma. Desse modo, a ação da alma sobre o corpo se dá, pois a alma, através da vontade, pode realizar uma agitação nos espíritos, alterar-lhes o seu curso. Em contrapartida, os espíritos, através destes mesmos movimentos, mobilizam a glândula pineal, provocando diversas percepções na alma. A glândula pineal é, pois, o locus no qual se estabelece o contato entre corpo e alma (Cf. As Paixões da Alma. I, 34-39). Quando o filósofo determina uma sede corpórea para a alma, mormente, pode conferir à relação alma e corpo um caráter mecânico e ainda, tentar responder, de forma mais detalhada, ao problema colocado pela distinção substancial.

${ }^{20}$ Em sentido estrito, Descartes não considera o homem um "espírito puro”, mas um “único todo”, composto de corpo e alma. O filósofo francês esclarece que embora possamos conceber pelo entendimento apenas a distinção substancial, a natureza nos ensina (pela experiência da dor, fome, sede, etc.) que alma e corpo estão estreitamente unidos, confundidos, misturados, de modo a formar um único todo (Cf. Meditações, VI, 23,24). Desse modo, tal união entre corpo e alma não é uma mera justaposição, mas uma conjugação ou uma mistura de duas substâncias. L. Teixeira, em seu Ensaio sobre a moral de Descartes, afirma ser essa união também uma substância, ao mesmo título que a alma e o corpo o são. Com efeito, a união é uma mistura ou confusão de duas substâncias, para formar uma terceira substância, ainda que contingente (Cf. TEIXEIRA, 1990, p.92). Não obstante, explicita o comentador, sendo confusa a idéia de união entre duas substâncias que, por 
Não obstante, isso não significa dizer que o filósofo alemão irá adotar a concepção cartesiana de corpo ou mesmo refutar a "espiritualidade” do homem (Cf. AC/AC, 14). Acreditamos que o que Nietzsche procura trazer à cena é a possibilidade de considerar também o espírito, bem como suas chamadas faculdades, um resultado de processos corpóreos:

A velha palavra "vontade” serve unicamente para designar uma resultante, uma espécie de reação individual que segue necessariamente uma multiplicidade de estímulos, em parte contraditórios, em parte concordantes (...) Para nós, o “espírito” é o sintoma de uma relativa imperfeição do organismo, um ensaiar, um tatear, cometer erros, um penoso trabalho em que se gasta, desnecessariamente, muita energia nervosa (AC/AC, 14).

Para Nietzsche, Descartes procurou eliminar quaisquer resquícios de natureza no homem, abstrair o corpo e encontrar um “fundamento", para além dos sentidos e do sistema nervoso. Entretanto, o corpo é o ponto de contato entre homem e animal e nem mesmo o filósofo francês, com seu “espírito puro”, conseguiu demonstrar o contrário.

Em Para Além de Bem e Mal, novamente, para fazer frente ao "espírito puro", vemos o filósofo identificar a "vontade fundamental do espírito” aos processos corpóreos

definição, existem por si mesmas e se concebem cada uma por um conceito que lhe é próprio, considerada esta idéia incompreensível ao entendimento, só resta a Descartes explicá-la pela vontade divina. Isso significa dizer que, ainda que o filósofo coloque como problema o fato de res cogitans e res extensa se encontrarem unidas substancialmente no homem, ele não procura resolvêlo. Mesmo a apresentação da glândula pineal, como sede da alma, não pretendeu resolver o problema da interação entre as duas substâncias: "É, pois, claro que Descartes afirma a ação da alma sobre o corpo através da glândula pineal: mas o fato de restringir à glândula a sede dessa ação não lhe ocorre que seja uma solução racional ao problema” (TEIXEIRA, p.98, 1990). A seu ver, Descartes admite uma ação real da alma sobre o corpo, ainda que não possa racionalmente explicá-la: “Trata-se de um mistério da natureza, de algo incompreensível ao entendimento humano, ainda que irrecusável fato da experiência” (TEIXEIRA, p.98, 1990). Cf. TEIXEIRA, L. Ensaio sobre a moral de Descartes. $2^{a}$ ed. São Paulo, Brasiliense \& Secretaria de Estado da Cultura, 1990. 
(Cf. JGB/BM, 230). Nessa passagem, procura colapsar as aspirações metafísicas à atribuição de uma outra natureza ao homem, na qual o “espírito” seria o testemunho de procedência superior. Destarte, em oposição à vaidade humana, que incita a busca de uma origem superior ao homem, ao “maneirismo” metafísico que insiste no mesmo rapell de ton sobre gêneses divinas, propõe um redirecionamento do homem para este mundo, o mundo natural:

Ou seja, reconverter o homem para a natureza; triunfar sobre as muitas interpretações e segundos sentidos vaidosos e delirantes que até agora foram rabiscados e pintados sobre aquele eterno texto fundamental homo natura; fazer com que o homem, doravante, fique diante do homem, como já hoje, endurecido na disciplina da ciência, ele fica diante da outra natureza, com intrépidos olhos de Édipo e tapados ouvidos de Odisseu, surdo aos engodos dos velhos passarinheiros metafísicos, que por demasiado tempo lhe flautaram ao ouvido; “Tu és mais! tu és superior! tu és de outra ascendência” (JGB/BM, 230).

Para o filósofo, reconverter o homem para a natureza é, pois, contrapor-se às camadas de pintura com as quais os metafísicos recobriram o homem, de modo a alçá-lo a uma outra natureza. Portanto, o recurso ao homo natura é o que o permite unir completamente o homem à natureza ${ }^{21} \mathrm{e}$, desse modo, afirmar que mesmo a atividade do espírito em nada se afasta dos demais processos do mundo. Com isso, julgamos que Nietzsche procura

\footnotetext{
${ }^{21}$ Na mesma medida em que Nietzsche recusa o “espírito puro” como algo distinto do corpóreo que caracterizaria, essencialmente, o homem, passa ao largo de propor o retorno a um estado de natureza originário. Na filosofia nietzschiana, reconverter o homem à natureza significa se afastar tanto da "tacanhez" mecanicista (Cf. JGB/BM, 21) de Descartes, quanto do "sentimentalismo" do estado de natureza de Rousseau (Cf. GM/GM, II, 17). No Crepúsculo dos Ídolos, o filósofo diz que, como Rousseau, quer o "retorno à natureza", mas não a um estado de perfeição originário, de igualdade e liberdade naturais, que julga não ser efetivo: “Também este aborto, que se alocou em meio ao umbral do novo tempo, queria o 'retorno à natureza' - para onde, uma vez mais indago, Rousseau queria retornar?” (GD/CI, Incursões de um Extemporâneo, 48).
} 
denunciar que é somente a partir da recusa do que há de "natureza” no homem, a irracionalidade, o domínio dos sentidos e do instinto desregrado, que a proposição do “espírito puro” ganha contorno preciso.

Todavia, em O Anticristo, critica todas as "ficções" criadas pelos metafísicos, como “alma”, “eu”, “espírito puro”, mas também o conceito de “natureza”. Sob sua óptica, é possível entrever certo “ranço metafísico” até mesmo nesse conceito, quando usado em referência a uma suposta “natureza humana” ou até mesmo quando atribuído ao chamado “mundo natural”:

Depois que o conceito natureza foi inventado como contra-conceito para "Deus”, “natural” tinha de ser a palavra para “reprovável” - aquele inteiro mundo de ficções tem sua raiz no ódio contra o natural (- a efetividade! -), é expressão de um profundo mal-estar com o efetivo... (AC/AC, 15).

Ele quer dizer que para os metafísicos, natureza e divindade não podem compartilhar o mesmo solo. Em outras palavras, o domínio do criador não deve confundir-se com o das criaturas. Por isso, operam uma divisão de mundos: este mundo, o da natureza, odioso, reprovável em seus acontecimentos e o outro mundo, em muito diverso, elevado, divino. Logo, é por ter por alvo de ataque a cisão de mundos realizada pelos metafísicos que Nietzsche opta pelo uso do termo “efetividade”.

Na mesma direção, no Crepúsculo dos Ídolos, diz que o mal-estar em relação ao corpo e aos processos efetivos é o que leva os metafísicos a realizarem uma vingança contra a vida, através da “fantasmagoria de uma 'outra' vida, de uma vida 'melhor'”, (GD/CI, A “razão” na filosofia, 6). Segundo o filósofo, operam uma divisão de mundos porque: “a morte, a mudança, a idade, do mesmo modo que a geração e o crescimento são para eles objeções - e até refutações” (GD/CI, A “razão” na filosofia, 1). Assim, se 
defendem a cisão da efetividade ${ }^{22}$ é porque procuram veementemente se afastar do perecimento e da morte iminentes, próprias ao corpo. Indispostos com o efetivo, eles procuram se identificar a um espírito vinculado a "outro” mundo, visto que o corpo está atrelado a "este” mundo, bem como a tudo o que lhe é próprio: os processos de geração, crescimento, perecimento e morte. Destarte, enaltecem o “outro" mundo, pois esse se remete à unidade, identidade, perenidade e indivisibilidade. Ao mesmo tempo, condenam “este” mundo, a efetividade, através da fabulação de uma “outra” vida em um mundo melhor.

Com efeito, para os metafísicos, a “vida após a morte” aparece como saída, em “outro” mundo, que não o efetivo. Entretanto, de modo a não incorrerem numa contradictio in adjecto, têm que salvaguardá-la em algo, que não o corpo. Ora, somente uma alma imortal $^{23}$ pode ter acesso à “outra vida”, pois se esquiva do perecimento, próprio ao corpo.

${ }^{22}$ Giacóia Jr., em Nietzsche como psicólogo, ao reconstituir a crítica de Nietzsche ao privilégio concedido à consciência pela filosofia e psicologia racionais, diz que, ao ver do filósofo alemão, a doutrina cristã da imortalidade da alma é uma interpretação vulgarizante do platonismo, e é ela que prepara as bases para a consolidação do que viria a ser a moderna cultura ocidental. O comentador afirma que, para Nietzsche, é de um platonismo difuso que se teria nutrido a crença inveterada no privilégio da parte racional da alma, fonte do conhecimento verdadeiro, pelo qual se atesta nosso parentesco originário com um mundo divino. Esclarece ainda que não haveria nenhuma possibilidade de partição do real em dois mundos se não fosse porque a alma é em nós o princípio que nos liga ao verdadeiro mundo, se não fosse o caráter e a natureza divina da nossa alma. Nessa matriz de pensamento, a parte racional de nossa alma seria, pois, de origem divina, superior ao corpo e distinta dele, sendo que: "A condição de que essa alma se volte para a sua pátria de origem e a ela retorne é a negação desse mundo das sombras, e, mais precisamente, do corpo" (GIACÓIA Jr., 2001, p.55). Assim, podemos dizer que é a vista do empenho nietzschiano em desvelar a trajetória que vai do pensamento platônico-cristão à modernidade o que conduz o comentador a afirmar que "a genealogia nietzschiana esforça-se por demonstrar a persistência desses mesmos pressupostos tanto no pensamento medieval quanto na filosofia moderna, sendo o dualismo de Descartes uma de suas mais significativas tentativas de transfiguração filosófica” (GIACÓIA Jr., 2001, p.55). Cf. GIACÓIA Jr., O. Nietzsche como psicólogo (Coleção Focus 6). Unisinos, 2001.

${ }^{23}$ Em $O$ Anticristo, Nietzsche diz que, falaciosas, a imortalidade da alma e a criação de um alémmundo despojam da vida todo sentido: "Se se põe o centro de gravidade da vida, não na vida, mas no 'além' - no nada -, tirou-se da vida toda gravidade. A grande mentira da imortalidade pessoal destrói toda razão, toda natureza que há no instinto - tudo o que é benéfico nos instintos, que 
Emblematicamente, em As Paixões da Alma, Descartes explica por que somente a alma pode resguardar-se da corrupção corpórea:

A morte nunca sobrevém por culpa da alma, mas somente porque alguma das principais partes do corpo se corrompe: e julguemos que o corpo do homem vivo difere do de um morto como um relógio (isto é, outra máquina que se mova por si mesma), quando está montado e tem em si o princípio corporal dos movimentos para os quais foi instituído, com tudo o que se requer para a sua ação, difere do mesmo relógio, ou outra máquina, quando está quebrado e o princípio de seu movimento pára de agir (As Paixões da Alma. I, 06).

Para o filósofo francês, a morte não se dá porque a alma deixa o corpo, no qual estava conjugada, em abandono. A alma não é princípio de constituição ou conservação do corpo, sendo assim, apenas a corrupção das estruturas corpóreas determina a morte. Ela em nada participa dos processos de perecimento; somente se ausenta após a corrupção consumada. Mas, se, para os metafísicos, o evento da corrupção corpórea marca a transição da alma imortal para um “outro” mundo, para Nietzsche, a alma mesma não está incólume aos processos corpóreos. Se os metafísicos advogam “outra” vida, da qual “esta” vida seria apenas o arremedo, para o filósofo alemão, somente é possível assegurar a inexorabilidade dos processos da efetividade.

Por esse viés, em Para Além de Bem e Mal, no contexto da crítica ao que denomina “atomismo da alma”, põe em questão a “crença” metafísica que vê a alma como algo indestrutível, eterno, indivisível. Singularmente, sua estratégia não é tomar partido do corpo, em detrimento da alma, mas apresentá-la com características do que, comumente, atribuímos ao corpóreo:

propicia a vida, que garante futuro, que desperta confiança. Viver de tal modo, que não tenha mais nenhum sentido viver, esse se torna agora o ‘sentido’ da vida...” (AC/AC, 43). 
Seja dito entre nós que não é necessário, absolutamente, livra-se com isso da "alma" mesma, renunciando a uma das mais antigas e veneráveis hipóteses (...) Está aberto o caminho para novas versões e refinamentos da hipótese alma: e conceitos como "alma mortal", "alma como pluralidade do sujeito" e "alma como estrutura social de impulsos e afetos" querem ter, de agora em diante, direitos de cidadania na ciência (JGB/BM, 12).

A partir de agora, a alma cartesiana, una, indivisível, incorruptível, pode concorrer com outras versões de alma. Versões nas quais assume características até então próprias ao corpo, como mortalidade, pluralidade, ser o locus de impulsos e afetos. E sob a mesma óptica, o corpo pode ser apresentado como "uma estrutura social de muitas almas" (JGB/BM, 19). Com isso, Nietzsche coloca em xeque a distinção substancial cartesiana, não por abrir mão da alma, mas por remeter corpo e alma a um mesmo registro: o da pluralidade de impulsos e afetos (Triebe und Affekete) ${ }^{24}$.

Em outro parágrafo de Para Além de Bem e Mal, conjetura a impossibilidade de descer ou subir a outra "realidade” a não ser a dos impulsos. A partir disso, afirma ser o pensar "apenas uma proporção desses impulsos entre si” (JGB/BM, 36). Nessa mesma trilha, na Genealogia da Moral, ao refletir sobre os tempos em que o homem passou a viver de forma gregária e pacífica, apresenta a alma sob a perspectiva dos impulsos que se interiorizaram. Os impulsos deixaram de ser os reguladores da ação dos homens e ficaram reduzidos a sua "consciência”, ao "pensar, inferir, calcular, combinar causa e efeito"

24 No conjunto de seus escritos, Nietzsche faz uso dos termos impulso (Trieb), afeto (Affekt) e, por vezes, instinto (Instinkt), de modo intercambiável. O termo força (Kraft), utiliza, principalmente, na exposição de sua tese cosmológica. O conceito vontade de potência (Wille zur Macht) aparece na obra publicada e, em grande parte, em fragmentos póstumos. Em nossa argumentação, será utilizado somente o termo impulso (Trieb), em uma acepção genérica, em referência aos processos da efetividade. Assim escolhemos, devido ao caráter dinâmico e ativo que o termo impulso (Trieb) comporta. 
(GM/GM, II, 16) ${ }^{25}$. Os homens, inibidos pelas injunções da vida gregária, tiveram seus instintos, os “velhos guias” do homem livre, selvagem e errante, voltados para dentro; "isto é o que chamo de interiorização do homem: é assim que no homem cresce o que depois se denomina sua 'alma’” (GM/GM, II, 16). Sendo assim, a alma não ultrapassa o campo da necessidade (Not) de obstrução da descarga dos impulsos, imposta pela vida gregária e pacífica. Nada de necessário (Notwendigkeit), em sentido metafísico, aqui se apresenta. Se, para Descartes, o pensamento é atributo de uma res cogitans, para o filósofo alemão, mesmo o pensar pode ser apresentado a partir das relações entre impulsos, tal como o agir, o sentir e o querer.

\footnotetext{
${ }^{25}$ Na mesma direção, no Livro V de A Gaia Ciência, sobre a consciência, Nietzsche argumenta que ela se desenvolveu sob a pressão da necessidade de comunicação entre os homens, que precisaram transmitir sua condição de indigência ao outro, com fins de auxílio e proteção. Como o animal mais ameaçado, o homem necessitou da vida gregária e de uma ponte de comunicação com os demais. "necessitava, em primeiro lugar, de 'consciência', portanto, de 'saber' ele mesmo o que lhe falta, de 'saber' como se sente, de 'saber' o que se pensa. Pois, para dizê-lo mais uma vez: o homem, como toda criatura viva, pensa continuamente, mas não sabe disso: o pensamento que se torna consciente é apenas a mínima parte dele, e nós dizemos: a parte mais superficial, a parte pior: pois somente esse pensamento consciente ocorre em palavras, isto é, em signos de comunicação: com o que se revela a origem da própria consciência” (FW/GC, V, 354). O desenvolvimento da consciência ocorreu por contingência, em resposta a uma situação de inópia. Nietzsche afirma que poderíamos pensar, sentir, querer, recordar e agir, sem que com isso algo precisasse "entrar na consciência”: "a vida inteira seria possível sem que, por assim dizer, se visse no espelho: como, de fato, ainda agora, entre nós, a parte preponderante dessa vida se desenrola sem esse espelhamento - e aliás também nossa vida de pensamento, sentimento, vontade, por mais ofensivo que isso possa soar a um filósofo mais velho (....)” (FW/GC, V, 354). O filósofo alemão assegura que não há nenhuma "necessidade" (Notwendigkeit) no "tomar-consciência-de-si” (Sich-Bewuszt-Werden). Com efeito, seria até mesmo possível abrir mão da consciência, afinal, a aptidão de comunicação se desenvolveu somente por uma necessidade (Not) de caráter arbitrário. Malgrado a ofensa que poderia infligir ao filósofo francês, a consciência é "supérflua"; um ermitão e um animal de rapina prescindiriam dela.
} 
Assim, Nietzsche pode recorrer à fisiologia ${ }^{26}$ para falar do espírito e afirmar que "suas necessidades e faculdades, aqui, são as mesmas que os fisiólogos estabelecem para tudo que vive, cresce e se multiplica” (JGB/BM, 230). Ele até mesmo apresenta a semelhança do espírito a um estômago e ressalta sua "força digestiva" em processos de assimilação, digestão e incorporação de experiências. Nessa mesma direção, na Genealogia da Moral, apresenta as assimilações de vivências, no mesmo registro das assimilações digestivas:

Um homem forte e bem logrado digere suas vivências (feitos e malfeitos incluídos) como suas refeições, mesmo quando tem de engolir duros bocados. Se não “dá conta” de uma vivência, esta espécie de digestão é tão fisiológica quanto a outra - e muitas vezes, na verdade, apenas uma conseqüência da outra (GM/GM, III, 16).

Como ambas as assimilações, psíquica (Einverseelung) e corpórea (Einverleibung), são processos fisiológicos, a cisão entre o "corporal” e o "espiritual” perde o sentido. Dessa forma, Nietzsche apresenta uma fisiopsicologia (Cf. JGB/BM, 23), na qual os chamados processos fisiológicos e psicológicos são igualmente “resultantes” das múltiplas interações estabelecidas entre impulsos.

\footnotetext{
${ }^{26}$ Para Müller-Lauter (1999), o conceito de fisiologia em Nietzsche não é inequívoco. Em suas obras, o filósofo evidencia três determinações gerais para o termo fisiologia, que se sobrepõem com freqüência: uma acepção teórico-científica, tal como utilizada pelas ciências de sua época; como determinação somática (por isso fundamental), remetida às funções orgânicas, ao afetivo no sentido do "imediato corpóreo" e como luta de quanta de potência que “interpretam”. Segundo o autor, é necessário ter por horizonte essa trindade, de modo a não nos atermos unicamente aos conhecimentos das ciências da natureza, com os quais Nietzsche teve contato, nem a um fisiologismo de cunho limitado, como mero determinismo de base fisiológica. Cf. MÜLLERLAUTER, W. Décadence artística enquanto décadence fisiológica: a propósito da crítica tardia de Friedrich Nietzsche a Richard Wagner (Trad: Scarlett Marton). Cadernos Nietzsche 06, São Paulo, 1999. p.11-30.
} 
Por essa perspectiva, o homem é uma configuração fisiopsicológica que resulta da interação de impulsos: “'L'effet c'est moi’: ocorre aqui o mesmo que em toda comunidade bem construída e feliz, a classe regente se identifica com os êxitos da comunidade” (JGB/BM, 19). Para Nietzsche, em analogia a uma comunidade onde são estabelecidos processos de dominação, uma configuração fisiopsicológica é resultante das múltiplas relações de mando e obediência estabelecidas entre impulsos. Nesse processo, essas interações ocorrem de modo combativo e sem termo. Isso significa dizer que a ação de impulsos pode ser traduzida por uma luta ${ }^{27}$ ininterrupta por domínio. Nesta, impulsos dominam ao mesmo tempo em que são dominados, vencem algumas resistências, mas subjugam-se a outras, formando uma rede hierárquica intricada e flutuante de interações. Isso explica a multiplicidade de configurações fisiopsicológicas como expressão variegada do efetivar-se de impulsos, que compõe no decorrer da luta as mais diversas ordenações hierárquicas. Com efeito, se o filósofo alemão faz referência a uma "estrutura social” de impulsos e afetos, é para essa inaudita hierarquia (Rangordnung) de mando e obediência que aponta.

Além disso, Nietzsche esclarece que, no decorrer da luta entre impulsos, sem que haja o aniquilamento dos combatentes, as ordenações hierárquicas de impulsos podem se desagregar, passando a compor outras formas na efetividade. Sendo assim, o que chamamos morte é a desagregação total de uma configuração fisiopsicológica que, fragmentada, irá compor outros arranjos. Destarte, através da apresentação do caráter perpétuo da luta e da explicitação das sucessivas desagregações que no decorrer dela

\footnotetext{
${ }^{27}$ Andler ressalta a predileção de Nietzsche pelo pensamento do biólogo alemão Wilhelm Roux, autor da Luta seletiva das partes do organismo (1881). Roux explica, a partir de uma perspectiva biomecânica, a dinâmica de formação dos organismos vivos, através da luta de suas mais ínfimas partes; partículas orgânicas, células, tecidos e órgãos. É no decorrer desta luta entre as partes do organismo, de seu conflito, que é garantida a configuração das estruturas orgânicas, bem como sua proliferação, e vantagem em relação aos demais organismos vivos. Cf: ANDLER, C. Nietzsche: sa vie et sa pensée. Paris, Gallimard, $4^{\mathrm{a}}$ ed. V.2. 1958.
} 
ocorrem, o filósofo coloca em xeque a dicotomia vida e morte ${ }^{28}$. De modo singular, Nietzsche diz ainda que, em uma mesma configuração fisiopsicológica, a cada momento, ordenações hierárquicas de impulsos podem se desestruturar, sem que ocorra a desagregação total. É por isso que, em Ecce Homo, ele afirma: "Paga-se caro por ser imortal: morre-se várias vezes em vida” (EH/EH, Assim falava Zaratustra, 5). Subvertendo o ponto de vista usual, onde os metafísicos enxergam dualismos, como corpo e espírito, vida e morte, o filósofo alemão vê apenas uma multiplicidade cambiante de impulsos em combate por precedência.

Com isso, o filósofo nos faz ver que mesmo o que denominamos de “espírito” é uma resultante dessas múltiplas relações de mando e obediência, do assenhorear-se e do sujeitar-se simultâneos de um conjunto de impulsos. Sob essa óptica, em Para Além de Bem e Mal, apresenta o espírito como resultado da atividade de um conjunto de impulsos que "quis" firmar-se como único, que "teve” uma vontade restritiva e "desejou” passar da multiplicidade à simplicidade (Cf. JGB/BM, 230). Num processo de simplificação, um conjunto de impulsos efetivou-se como determinada configuração hierárquica e firmou-se como um “Eu”. Desse modo, não há um “Eu”, aos moldes cartesianos, responsável pelos atos de mandar e obedecer. Há somente uma “pluralidade de sujeitos” sequiosos por mando e precedência, estabelecendo interações nas quais, ao mesmo tempo, se obedece e se manda e, mandando, se cumpre obediência:

Somos ao mesmo tempo a parte que comanda $e$ a que obedece, e como parte que obedece conhecemos as sensações de coação, sujeição, pressão, resistência, movimento (...) por outro lado, temos o hábito de ignorar e nos enganar quanto a essa dualidade, através do sintético conceito de “eu” (JGB/BM, 19)

\footnotetext{
${ }^{28}$ É por identificar a vida às relações de domínio, estabelecidas entre impulsos, que Nietzsche a apresenta como "essencialmente apropriação, ofensa, sujeição do que é estranho e mais fraco, opressão, dureza, imposição de formas próprias, incorporação e, no mínimo e mais comedido, exploração” (JGB/BM, 259).
} 
Pelo seu viés, o “espírito puro”, a una, indivisível e incorruptível res cogitans é apenas o resultado de um processo de simplificação do "querer" tomar precedência de uma multiplicidade de impulsos em combate.

Não obstante, apesar de Nietzsche atribuir aos impulsos um "querer”, nos alerta que não são agentes de uma ação. Ele esclarece que não existe um "substrato" para a ação de impulsos: “o agente é uma ficção acrescentada à ação - a ação é tudo” (GM/GM, I, 13). Equivocadamente, Descartes tomou de empréstimo o "eu" da linguagem para servir de agente ao pensamento. Por isso, alterca o filósofo alemão, ao deduzir do ato de pensar um "eu” que pensa, um sujeito, uma res cogitans, ele se enredou num mero "hábito gramatical”:

Quanto à superstição dos lógicos, nunca me cansarei de sublinhar um pequeno fato que esses supersticiosos não admitem de bom grado - um pensamento vem quando "ele" quer e não quando "eu quero", de modo que é um falseamento da realidade efetiva dizer: o sujeito "eu" é a condição do predicado "penso". Isso pensa: mas que esse "isso" seja precisamente o velho e decantado 'eu’ é, dito de uma maneira suave, apenas uma suposição, uma afirmação, e certamente não uma "certeza imediata". (...). Aqui se conclui segundo o hábito gramatical: "pensar é uma atividade, toda a atividade requer um agente, logo -“(JGB/BM, 17).

Ele revela que o esquema cartesiano está pautado no modelo lógico-gramatical SujeitoPredicado-Objeto, que faz derivar da ação pensar (Predicado), um agente para a ação (Sujeito) e, ainda, uma idéia (Objeto). Com isso, Nietzsche revela que é a partir de um preconceito lógico-gramatical que Descartes encontrou seu "Eu" e a ele atribuiu estatuto ontológico. 
Nesta mesma direção, em outro parágrafo de Para Além de Bem e Mal, estrategicamente, faz uso do segundo preceito metódico cartesiano ${ }^{29}$ para evidenciar, através da própria artilharia do filósofo francês, em que medida ele não conseguiu desvencilhar-se da "sedução da linguagem”:

Se eu decomponho o processo que está expresso na proposição “eu penso”, obtenho uma série de afirmações temerárias, cuja fundamentação é difícil, talvez impossível -, por exemplo, que sou eu quem pensa, que em geral tem de haver algo que pensa, que pensar é uma atividade e efeito da parte de uma essência que é pensada como causa, que há um “eu” e, enfim, que já está estabelecido firmemente o que se deve designar como pensar - que eu sei o que é pensar. Pois, se eu já não tivesse decidido sobre isso comigo mesmo, em que me basearia para distinguir se o que acaba de acontecer não é, talvez, “querer” ou “sentir”? Basta dizer que aquele "eu penso" pressupõe que eu compare meu estado no instante com outros estados que conheço em mim, para assim estabelecer o que ele é: dada essa remetência a um saber de outra precedência, ele não tem para mim, em todo caso, nenhuma certeza imediata - (JGB/BM, 16).

Descartes deduziu do “pensar”, um agente ao pensamento, um “eu” como causa do ato de pensar, e, como último elo da cadeia, a existência do eu como substância, como coisa pensante (res cogitans). Contudo, para estabelecer o que seria o pensar, necessitou de um saber de outra procedência. Lançou mão da comparação com outros estados, como o sentir e o querer, para determinar o que seria o pensamento. De tal modo que outros estados, até mesmo a sensibilidade, concorreram para a afirmação da certeza cartesiana. Desta vista,

\footnotetext{
${ }^{29}$ No Discurso do Método, Descartes apresenta seu segundo preceito metódico: “dividir cada uma das dificuldades que eu examinasse em tantas parcelas quantas possíveis e quantas necessárias fossem para melhor resolvê-las.” (Cf. Discurso do Método, II, p.45-46).
} 
Nietzsche conclui que o filósofo francês não alcançou nada de “imediato” como, em princípio, julgava $^{30}$.

Para Nietzsche, o pensar se dá na ação de impulsos, assim como o pensamento consciente, expresso em linguagem, é um efetivar-se de impulsos, que "tomou a palavra"31. Sendo assim, quando um pensamento subitamente emerge em palavras, é a mais simples expressão do combate: “Ouve-se, não se procura; toma-se, não se pergunta quem dá; um pensamento reluz como relâmpago, com necessidade, sem hesitação na forma - jamais tive opção” (EH/EH, Assim falou Zaratustra, 3). Por isso, o filósofo diz que, para alguns, é difícil afastar a idéia de ser mera encarnação, mero porta-voz, mero medium de forças poderosíssimas. Além disso, esclarece que grande parte do que se processa na luta de impulsos não se torna consciente e a linguagem sequer tangencia o que ocorre nos “subterrâneos” das configurações fisiopsicológicas: “nossas vivências mais próprias, não são nada tagarelas. Não poderiam comunicar-se, se quisessem. É que lhes falta a palavra” (GD/CI, Incursões de um Extemporâneo, 26). Há um universo de inefabilidade, de incomunicabilidade que, involuntariamente, toma parte no dizer "Eu”, ocorre um combate

\footnotetext{
${ }^{30}$ No entanto, nos Princípios da Filosofia, Descartes explica: “pelo termo 'pensamento' entendo todas aquelas coisas que, estando nós conscientes, ocorrem em nós, na medida em que há em nós uma consciência delas. E assim, não apenas entender, querer, imaginar, mas também sentir é aqui o mesmo que pensar" (Princípios da Filosofia, I, IX). Ainda, afirma que todos os modos de pensar podem ser referidos a dois gerais, a saber, a percepção ou a operação do entendimento e a volição ou a operação da vontade; "Pois sentir, imaginar e entender pelo puro entendimento são apenas diversos modos de perceber, assim como desejar, abominar, afirmar, negar, duvidar são diversos modos do querer" (Princípios da Filosofia, I, XXXII). Isso significa dizer que, Descartes, mesmo ao remeter-se ao imaginar ou ao sentir, não ultrapassa o campo da res cogitan. No limite, o filósofo se remete aos modos do próprio pensamento (a intelecção, a imaginação, a recordação, a volição etc.) e não a um saber de "outra procedência”, como denunciava o filósofo alemão. Cf: DESCARTES, R. Princípios da Filosofia.[edição bilíngüe latim/português] (Trad: Guido Antônio de Almeida, Raul Landim Filho, Ethel M. Rocha, Marcos Gleizer e Ulysses Pinheiro). Rio de Janeiro. Ed. UFRJ, 2002.

${ }^{31}$ Formada para expressar o mediano e o inteligível a todos, através da consciência, "é o instinto de rebanho que, com ela, afinal, toma a palavra (e também as palavras)” (GM/GM, I, 2).
} 
silencioso, do qual vem à tona, em linguagem, somente um ou outro resultado da contenda que se trava.

Entretanto, o filósofo francês se aferrou ao resultado do combate e ignorou que por trás de seu "Eu” há uma multiplicidade de fileiras de impulsos que ora entoam gritos de guerra, ora são subjugados em silêncio. Ele sequer suspeitou que há uma "grande razão", em nada distinta do corpo, que apenas procede como “Eu”: ““Eu’ - dizes; e ufanas-te desta palavra. Mas ainda maior - no que não queres acreditar - é o teu corpo e a sua grande razão: esta não diz eu, mas faz o eu” (Za/ZA, I, Dos desprezadores do corpo). De outro modo, dentre os desprezadores do corpo, Descartes procurou afirmar ser uma coisa pensante e inextensa e ter a certeza de que; "este eu, isto é, minha alma, pela qual sou o que sou, é inteira e verdadeiramente distinta de meu corpo e que ela pode existir sem ele" (Meditações. VI, 17). Todavia, se a "pequena razão" cartesiana guarda, por principio, completa independência do corpóreo, através da "grande razão", Nietzsche revela que esta lhe é apenas instrumento:

Instrumentos e brinquedos são os sentidos e o espírito; atrás deles acha-se, ainda o ser próprio, O ser próprio procura também com os olhos dos sentidos, escuta também com os ouvidos do espírito. E sempre o ser próprio escuta e procura: compara, subjuga, conquista, destrói. Domina e é, também, dominador do Eu. Atrás de teus pensamentos e sentimentos, meu irmão, acha-se um soberano poderoso, um sábio desconhecido - e chama-se o ser próprio. Ele habita no teu corpo, é o teu corpo (...) O corpo criador criou o espírito como a mão da sua vontade (Za/ZA, I, Dos desprezadores do corpo).

Como instrumento do corpo, o espírito é guiado por injunções que nem sequer suspeita. É, pois, uma "grande razão" o que dita à "pequena razão" seus pensamentos e palavras. Assim, de modo sagaz, Nietzsche não pede aos desprezadores do corpo que mudem de 
opinião ou doutrina, mas os incita a se desfazerem de seus próprios corpos, o que os tornaria mudos (Cf. Za/ZA, I, Dos desprezadores do corpo). Descartes, ao despojar-se do corpo, colocaria em xeque a possibilidade mesma de um filosofar e estaria condenado definitivamente ao mutismo.

Malgrado isso, o filósofo francês argumenta, em suas Meditações, sobre a maior facilidade em conhecer o espírito que o corpo $^{32}$. Em sua perspectiva, o espírito é conditio sine qua non de acesso ao corpóreo. Em Para Além de Bem e Mal, Nietzsche contra$\operatorname{argumenta}^{33}$; “todo impulso ambiciona dominar: e portanto procura filosofar” (JGB/BM, 6). De modo adverso, para ele, o corpo é a condição mesma do filosofar, do pensamento, da palavra. Além disso, revela que são as injunções do próprio corpo que ditam a proeminência do espírito: “Acreditai-me, meus irmãos! O corpo que desesperava do corpo foi ele que andou tateando, com os dedos perturbados do espírito, as últimas paredes” (Za/ZA, I, Dos Ultramundanos). Mais explicitamente, aclara que foi o corpo moribundo que ditou o desprezo ao corpo. Afinal, “[o corpo] para eles é uma coisa enferma, e muito gostariam de sair da sua pele” (Za/ZA, I, Dos Ultramundanos). Isso esclarece por que Descartes procurou “sair dessa pele”, afastar-se do corpo, do “rosto, mãos, braços e toda essa máquina composta de ossos e carne, tal como ela aparece em um cadáver” (Meditações. II, 06), fiando-se à algum atributo da alma. E, ainda, por que apresentou um

\footnotetext{
${ }^{32}$ Mais especificamente, na Meditação Segunda, intitulada "Da natureza do espírito humano e como ele é mais fácil de conhecer do que o corpo” (Cf. Meditações. II).

${ }^{33}$ No Livro V de A Gaia Ciência, Nietzsche faz uma alusão ao método cartesiano, que exige que tomemos o mundo interior, mais familiar para nós, como critério para conhecermos o exterior, o que nos está fora de nós. Ele critica a intenção dos homens do conhecimento de encontrar "por trás” das coisas a tabuada, a lógica, o querer, o desejar: "Também os mais cautelosos entre eles acham que ao menos o familiar é mais facilmente cognoscível do que o estranho, que o método exige, por exemplo, que se parta do 'mundo interior', dos 'fatos da consciência', pois este é o mundo mais familiar para nós! Erro dos erros! O familiar é o habitual: e o habitual é o mais difícil de 'conhecer’, isto é, de ver como problema, como alheio, distante, 'fora de nós'” (FW/GC, V, 355). Por fim, apresenta o processo de conhecimento assentado no "instinto do medo". No fundo, é o medo do inabitual, do duvidoso que nos inquieta e faz com que tomemos o "estranho", o "fora" de nós por objeto (idéia).
} 
corpo máquina, inteligível na totalidade de seus processos, passível às investidas reparadoras.

Por fim, Nietzsche revela que a revolta contra os processos da efetividade é ditada secretamente pelo corpo, devido ao perecimento e morte iminentes de dadas configurações fisiopsicológicas. Haja vista que os desprezadores do corpo sofrem com a efetividade, desprezam o corpo, pois este expressa a inexorabilidade de seus processos de modo mais patente. Para eles, os processos de mudança, perecimento e morte são intoleráveis e, de algum modo, precisam ser controlados. Como estratégia, tentam capturar o corpo a partir dos critérios da "pequena razão” e circunscrevê-lo na univocidade de um sentido. Assim, toda tentativa de apresentar uma “verdade” sobre o corpo, conceitualizá-lo, é sinal de perecimento de uma configuração fisiopsicológica. Mas, ele se esquiva e torna-se sempre outro em relação àquilo em que anteriormente se firmava. Ele é mudança perpétua e, portanto, polissêmico ${ }^{34}$. Destarte, por ser estratégia daqueles que sofrem com o efetivo, Nietzsche pode furtar-se de atribuir um único sentido ao corpo. Em seu entender, para o conceito corpo há uma multiplicidade de sentidos, própria aos processos dinâmicos da efetividade.

\footnotetext{
${ }^{34}$ No Livro V de A Gaia Ciência, Nietzsche diz que um mundo mecânico seria "pobre de sentido", pois nele tudo poderia ser contado, calculado, posto em fórmulas: "O mesmo se dá com a crença que hoje em dia satisfaz tantos cientistas naturais materialistas, a crença num mundo que deve ter a sua equivalência e medida no pensamento humano, em humanos conceitos de valor, um 'mundo da verdade', a que pudéssemos definitivamente aceder com a ajuda da nossa pequena e quadrada razão - como? queremos de fato permitir que a existência nos seja de tal forma degradada a mero exercício de contador e ocupação doméstica de matemáticos? Acima de tudo, não queremos despojá-la de seu caráter polissêmico; é o bom gosto que o requer meus senhores, o gosto da reverência ante tudo o que vai além de seu horizonte!” (FW/GC, V, 373)
} 


\title{
CAPÍTULO II:
}

\section{O diagnóstico da grande saúde: ensaio, experimentação e criação}

\author{
Mil veredas há, que nunca foram andadas ainda, \\ mil saúdes e ilhas escondidas da vida. \\ Inesgotados e inexplorados estão ainda o homem e a terra do homem
}

(NIETZSCHE)

Nietzsche, ao afirmar que toda concepção de corpo é ditada pelo corpo mesmo, revela que todo conceber é um entender e um engendrar, como criação de um pensamento em um ventre corpóreo. É nessa direção que, no prefácio de A Gaia Ciência, ele assevera que os filósofos não têm a liberdade de separar o corpo da alma, pois não somos “rãs pensantes”, nem “aparelhos de objetivação e máquinas registradoras com vísceras congeladas” (FW/GC, Prefácio, 3). Sendo assim, de modo a expor a visceralidade de todo pensamento, afirma ser o filosofar a “arte de transfiguração” do corpo em espírito. Além disso, deixa entrever que, inerente a toda parturição, o processo de nascimento de uma filosofia não prescinde da dor (Cf. FW/GC, Prefácio, 3). Por isso, ainda na mesma obra, diz ser o criador (Zeuger) uma “pessoa-mãe”, alguém que sabe de gravidezes e partos do espírito (Cf. FW/GC, V, 369). E uma vez que recorre à gravidez e ao parto para expressar os processos de criação filosófica, dá às suas palavras uma conotação sanguínea. Em sua autobiografia, diz que em seus escritos as palavras são cobertas de sangue, vividas, profundas, interiores e que nelas estão presentes os maiores sofrimentos, mas sem que as feridas sejam sentidas como obstáculos (Cf. EH/EH, As extemporâneas, 3).

Com isso, o filósofo procura denunciar que é somente através de uma perspectiva demasiado estreita e "superficial” que se faz possível advogar uma separação entre os domínios fisiológico e psicológico, pois toda filosofia é sintoma das múltiplas relações de mando e obediência, estabelecidas no decorrer da luta de impulsos. Portanto, se, 
ironicamente, é por uma questão de corpo que os metafísicos se apegam à perspectiva da consciência, à univocidade de sentido da "pequena razão”, de igual modo, se Nietzsche afirma a polissemia dos processos efetivos e se opõe à separação entre corpo e alma e a toda sorte de dualismos que daí decorrem, longe de ser sua atitude uma opção puramente espiritual, assim se posiciona porque apresenta distinta índole de corpo (Cf. FW/GC, Prefácio, 2). De modo mais preciso, é por assumir diferente perspectiva em relação à tradição filosófica que, em sua autodiagnose tipológica, se considera dotado de grande saúde.

Com efeito, como psicólogo, Nietzsche toma por critério diagnóstico de saúde ou doença o ensaio de hierarquias de impulsos, enquanto abertura de possibilidade para experimentação de diferentes modos de querer, sentir e pensar. No Crepúsculo dos Ídolos, afirma que efetividade nos mostra "uma riqueza fascinante de tipos, a exuberância própria de um pródigo jogo e mudança de formas” (GD/CI, Moral como Contranatureza, 6) que, de acordo com as diferentes ordenações hierárquicas formadas no decorrer da luta de impulsos, adotam perspectivas as mais diversas (Cf. FW/GC, V, 374). Por esse viés, diagnostica que o estreitamento perspectivo da filosofia metafísica é expressão de décadence e, através do mesmo olhar, que sua filosofia, por resultar da maestria em “transtrocar perspectivas” (Cf. EH/EH, Por que sou tão sábio, 1), é sintoma de grande saúde. Desse modo, se se considera um tipo saudável, malgrado seus freqüentes episódios de doença, é porque diagnosticou que os tipos doentios não são, necessariamente, aqueles que vivenciam uma enfermidade, mas os que adotam uma estreita perspectiva, os que se atém a um único ponto de vista.

Mas, se por esse prisma diz ser uma diferença perspectiva o que faz com que seu pensamento difira do da tradição filosófica, como genealogista, ao aventar o “caráter perspectivístico das estimativas de valor” (MAI/HHI, prefácio, 7), faz com que sua diagnose receba outro matiz. No âmbito genealógico, ele ancora o diagnóstico da grande 
saúde e da décadence nas “tábuas de bens”, vistas como sintoma e medicamento para os tipos que as impôs. Nesse registro, parte do pressuposto que é somente por ser um recorte da efetividade que o homem pode se reputar como o que valora e mede, como o "animal estimador” (GM/GM, II, 8). Através disso, o filósofo deseja mostrar que a sede dos valores não se encontra em um além-mundo, mas que é do homem que provém todo sentido e valor:

Em verdade, foram os homens a dar a si mesmos o seu bem e o seu mal. Em verdade, não o tomaram, não o acharam, não lhes caiu do céu em forma de voz. Valores foi somente o homem que pôs nas coisas, para se conservar - foi ele somente que criou sentido para as coisas, um sentido de homem! Por isso ele se chama de 'homem', isto é: o estimador (Za/ZA, Dois mil e um alvos).

Com isso, Nietzsche acaba por denunciar que se os metafísicos procuram despojar a efetividade de seu caráter polissêmico é porque, ao estarem em processo de décadence, permanecem restritos à criação de ardis de autoconservação. De outro modo, por se considerar expressão de um dinâmico efetivar-se de impulsos, o filósofo se considera dotado de grande saúde para realizar a tarefa de criação de valores (Cf. JGB/BM, 211). Destarte, através de sua diagnose tipológica, ele procura tanto fazer uma crítica à décadence de seu tempo quanto aventar a necessidade de uma grande saúde àqueles que intentam criar valores, que não mais expressem aspirações contrárias aos processos efetivos.

Em suas exposições sobre a grande saúde, Nietzsche a apresenta como uma saúde necessária àqueles que querem experimentar diferentes modos de querer, sentir e pensar. Isso porque, a partir de um olhar retrospectivo, o filósofo percebeu que foi sua saúde o que lhe ofereceu condições para realizar inúmeras experimentações com o pensamento. Com 
efeito, no prefácio ao primeiro volume de Humano demasiado humano, ao reputar que a singularidade de todo pensar encontra esteio nas diferentes ordenações hierárquicas, formadas no decorrer da luta de impulsos, esclarece que, em seu próprio caso, teve que transitar por inúmeros estados de corpo para somente então poder divisar seu problema filosófico:

Suposto que seja do problema da ordenação hierárquica que podemos dizer que ele é nosso problema (...) tínhamos que experimentar os estados mais múltiplos e contraditórios de indigência e felicidade na alma e no corpo, como aventureiros e circunavegadores daquele mundo interior que se chama "homem", como medidores daquele "superior" e "um-sobre-o-outro" que igualmente se chama “homem” (MAI/HHI, Prefácio, 7).

Por considerar ser o homem um processo de composição de distintas ordenações hierárquicas de impulsos, o filósofo o exibe como um escalonamento cambiante, no qual a cada mudança de arranjo que se efetiva, uma diferente perspectiva se impõe. Por isso, ao rever sua trajetória, ele conclui que foi o maior dinamismo desse “um-sobre-o-outro" de impulsos, que o caracteriza, o que permitiu que adotasse larga gama perspectiva e que sua tarefa filosófica pudesse "tomar corpo" e "vir ao mundo".

Ainda nesse prefácio, Nietzsche nomeia de grande saúde essa prerrogativa, como direito e vantagem de poder transitar por vários estados de corpo e realizar experimentações com o pensamento. Para figurá-la, recorre à expressão ${ }^{35}$ : “ $a$ perigosa

\footnotetext{
${ }^{35}$ Blondel defende que é necessário dar a devida atenção às metáforas, às imagens e, em linhas gerais, às formas de discurso que Nietzsche utiliza para expressar seu pensamento. Ele acredita que a metafórica nietzschiana não é uma "busca poética ou pura literatura destinada a seduzir os filólogos ou entusiasmar os adolescentes” (BLONDEL, 2004, p.8). Por isso, procura mostrar, através do problema da cultura, que as metáforas que o filósofo lança mão se impõem por uma necessidade especificamente filosófica. Também entendemos que Nietzsche recorre às imagens de modo a dar maior vivacidade às suas idéias; lança mão das metáforas, pois acredita que, por
} 
prerrogativa de viver para o ensaio e poder oferecer-se à aventura” (MAI/HHI, Prefácio, 4). Desse modo a apresenta, pois entende ser a maior mobilização de impulsos na luta, o ensaio de diferentes perspectivas, o que fomenta a exploração e a descoberta de diferentes ópticas e pontos de vista ${ }^{36}$. A seu ver, é esse dinamismo, assemelhado a uma dança ${ }^{37}$ de impulsos, o que promove a experimentação de pensamentos e valores, sentimentos e quereres outros. Por esse viés, mesmo a doença, como mobilização do corpo, pode dar oportunidade para experimentações de muitos e opostos modos de pensar (Cf. MAI/HHI, Prefácio, 4).

Com efeito, no quinto livro de A Gaia Ciência, é com a dança que Nietzsche cinge o parágrafo intitulado A grande saúde. No parágrafo que o antecede, diz: “eu não saberia o que o espírito de um filósofo mais gostaria de ser, senão um bom dançarino” (FW/GC, V, 381), no que o sucede, faz um convite à dança (Cf. FW/GC, V, 383). Acreditando ser a

induzirem movimento, operarem deslocamentos de sentido, melhor expressam o efetivar-se dinâmico de impulsos. Cf. BLONDEL, E. Nietzsche: a vida e metáfora (Trad: Fernando de Moraes Barros). Cadernos Nietzsche, São Paulo, Discurso Editorial, 16 (2004). p.07-51.

${ }^{36}$ Na Genealogia da Moral, esclarece: “existe apenas uma visão perspectiva, apenas um 'conhecer' perspectivo, e quanto mais afetos permitirmos falar sobre uma coisa, quanto mais olhos, diferentes olhos, soubermos utilizar para essa coisa, tanto mais completo será nosso 'conceito' dela, nossa 'objetividade'” (GM/GM, III, 12). Nessa passagem, explica que quanto mais impulsos em atividade, mais amplo é o espectro de perspectivas. Esclarece que quanto mais hierarquias de impulsos se efetivam, mais olhares entram em cena, mais vasto é o campo de visão e, assim, maior é o "conhecimento" sobre a coisa. Desse modo, não há observações desinteressadas, olhares para além ou aquém da dinâmica de impulsos. Não à toa, nessa passagem, recorre às aspas para o uso do termo "conceito". Longe de ser uma abstração, um conceito emerge da dinâmica mesma das hierarquias de impulsos que se efetivam e das perspectivas que daí se impõem.

37 Acompanhamos Marton, em seu ensaio “A dança desenfreada da vida”, quando afirma que Nietzsche espera, sobretudo aclarar que a dança, enquanto movimento, cadência, leveza, alegria, é determinante na maneira pela qual concebe sua filosofia: "Cadência, a dança põe em xeque a aparente imobilidade das coisas, a rigidez imposta ao pensamento, a fixidez forjada pelas palavras. Com o ritmo, o mundo deixa de ser estável, com os gestos, a linguagem deixa de ser unívoca. E as idéias ganham leveza” (MARTON, 2001, p.60). Cf. MARTON, S. Extravagâncias: ensaios sobre a filosofia de Nietzsche (Coleção Sendas e Veredas). Discurso Editorial / Editora UNIJUÍ, 2a edição. 2001. 
maior vivacidade na dança ${ }^{38}$ de impulsos o que promove a abertura de gamas perspectivas, das mais estreitas às mais abrangentes, afirma ser essa “nova saúde” necessária a todos aqueles que querem experimentar os mais diversos pontos de vista:

Aquele cuja alma tem sede de viver o âmbito inteiro dos valores e anseios que prevaleceram até agora e de circunavegar todas as costas desse "mar mediterrâneo" ideal, aquele que quer saber, pelas aventuras de sua experiência mais própria, o que se passa na alma de um conquistador e explorador do ideal, assim como de um artista, de um santo, de um legislador, de um sábio, de um erudito, de um devoto, de um adivinho, de um apóstata no velho estilo: este precisa, para isso, primeiro que tudo, de uma coisa, da grande saúde - de uma saúde tal, que não somente se tem, mas que também constantemente se conquista ainda, e se tem de conquistar, porque sempre se abre mão dela outra vez, e se tem de abrir mão!... (FW/GC, V, 382).

Além disso, deixa entrever que do horizonte de sua "saúde mais forte, mais engenhosa, mais tenaz, mais temerária, mais alegre, do que todas as saúdes que houve até agora” (FW/GC, V, 382), nem mesmo a “perda da saúde” pode ser excluída, pois também esta pode dar ensejo à adoção de inusitadas ópticas. Portanto, ao apresentar a grande saúde através do imperativo do abrir mão e da conquista, pelo viés do tornar-se sadio (Gesundwerden) e não pelo do ser sadio (Gesundsein), alude que aquele que está disposto a

${ }^{38}$ Santiago Guervós, em seu artigo Nos limites da linguagem: Nietzsche e a expressão vital da dança, defende que a insistência do filósofo em utilizar o simbolismo da dança em seus escritos é outra maneira de exaltar e reivindicar o valor do corpo. Além disso, comenta que, ao dançar com os conceitos, Nietzsche introduz neles a perspectiva, a crença que nenhum deles é estanque, que se valem para hoje, amanhã poderão ser diferentes. Para o filósofo, a alegria é a "liberdade bailarina do pensamento”, que compreende o mundo numa cena móvel de possibilidades cambiantes, como multiplicidade de perspectivas, pontos de vista. Por isso, Zaratustra será sempre um dançarino: “Afinal, quem é aquele que expressa melhor a alegria e a 'grande saúde', que é aquele que melhor sabe rir e o que melhor festeja a vida, a não ser o dançarino?” (GUERVÓs, 2003, p.97). Cf. SANTIAGO GUERVÓS, L.E. Nos limites da linguagem: Nietzsche e a expressão vital da dança (Trad: Alexandre Filordi de Carvalho). Cadernos Nietzsche 14, São Paulo, 2003. p.83-30. 
adotar inúmeras perspectivas não pode excluir nem mesmo a doença de seu campo de experimentações.

Com efeito, no prefácio ao primeiro volume de Humano demasiado humano, apresenta a grande saúde como uma "saúde transbordante” que não pode prescindir nem mesmo da doença, como um meio de apreensão de conhecimentos:

Desse isolamento doentio, do deserto desses anos de ensaio, o caminho ainda é longo até aquela descomunal segurança e saúde transbordante, que não pode prescindir nem mesmo da doença, como um meio e anzol do conhecimento, até aquela madura liberdade do espírito que é também autodomínio e disciplina do coração e permite os caminhos para muitos e opostos modos de pensar - aquela interior envergadura e mimo do excesso de riqueza que exclui de si o perigo de que o espírito porventura se perca em seu próprio caminho e se enamore de si e em algum canto fique sentado, inebriado, até aquele excedente de forças plásticas, regeneradoras, conformadoras e restauradoras, que é justamente o sinal da grande saúde (...) (MAI/HHI, Prefácio, 4).

No contexto desse prefácio, Nietzsche diz ter sido sua saúde o que impediu seu espírito de paralisar-se em uma única perspectiva, de acomodar-se em um estreito ponto de vista. Ele avalia que foi um sinal de grande saúde o ter podido experimentar diversos modos de querer, sentir e pensar, ter colocado em questão valores cristalizados pela tradição, ter revisitado suas adesões e rupturas afetivas e filosóficas.

Na mesma direção, no prefácio de A Gaia Ciência, relata que cada variação em seu estado de saúde lhe ofereceu um ensejo para experimentação de diferentes modos de filosofar. Dessa forma, mostra-se grato a seus episódios de enfermidade e enaltece sua saúde mutável, pois a vê como sua prerrogativa filosófica (Cf. FW/GC, Prefácio, 3). Conclui que, em sua trajetória, a possibilidade de questionar de modo cada vez mais aprofundado, de ultrapassar o conforto da mediania filosófica, foi oferecida pela sensação 
contínua da dor, ocasionada pela vivência da enfermidade: "Duvido que uma tal dor ‘melhore’ - mas sei que ela nos aprofunda” (FW/GC, Prefácio, 3). Assim, vê a doença como a "mestra da grande suspeita”, como o que o fez colocar em questão o usitado e, por isso, o que lhe ofereceu oportunidade de divisar problemas com os quais até então nunca havia se deparado.

A nosso ver, isso explica por que, como insígnias de sua filosofia, Nietzsche faz figurar o circunavegador, o explorador e o aventureiro como "espíritos fortalecidos por guerras e vitórias, aos quais a conquista, a aventura, o perigo, até mesmo a dor, se tornaram necessidade” (GM/GM, II, 24), andarilhos habituados ao "ar cortante das alturas, de andanças de inverno, de gelo e montanhas em todos os sentidos” (GM/GM, II, 24), argonautas, acostumados ao calor das “costas do mar mediterrâneo” (FW/GC, V, 382). Assim, se ele torna essas figuras emblemáticas, é porque, tal como um filósofo que experimenta diversos modos de pensar, até mesmo ante ao sofrimento e à dor, elas transitam entre os ambientes mais inóspitos aos mais amenos, peregrinam dos cumes gelados às planícies, navegam nos mares calmos e enfrentam as tempestades em alto-mar e, no entanto, ao contrário de sucumbirem, destas múltiplas experiências, saem ainda mais fortalecidas.

Por isso, em Ecce Homo, por outro olhar retrospectivo, Nietzsche afirma ter adoecido com freqüência, mas nunca ter se tornado doentio: "Minha prerrogativa é ter a suprema finura para todos os signos de instintos sadios. Falta em mim qualquer traço doentio; mesmo nos tempos de mais grave doença, nunca me tornei doentio” (EH/EH. Por que sou tão esperto, 10). Ora, ao analisar suas vivências, percebeu que seus episódios de enfermidade serviram de "estimulante" à luta de impulsos, possibilitaram que adotasse diferentes perspectivas. Logo, conclui que para alguém tipicamente sadio "o estar-doente pode até mesmo ser um energético estimulante a vida, à mais-vida” (EH/EH, Por que sou tão sábio, 2). Nessa direção, em $O$ caso Wagner, afirma: “a própria doença pode ser um 
estimulante da vida: mas é preciso ser sadio o bastante para esse estimulante!” (WA/CW, 5). Portanto, ao explicitar que seu critério diagnóstico concerne ao "transtrocar perspectivas” (Cf. EH/EH, Por que sou tão sábio, 1), dá testemunho de saúde ao ter adotado até mesmo a estreita perspectiva da décadence:

A partir da óptica do doente, olhar para os conceitos e valores mais sadios e, inversamente, da plenitude e certeza da vida rica, olhar para baixo e ver o secreto trabalho do instinto de décadence - esse foi meu mais longo exercício, minha experiência propriamente dita e, se é que em algo, foi nisso que me tornei mestre. (EH/EH, Por que sou tão sábio, 1)

Ao admitir ter vivenciado essa “dupla série de experiências” (Cf. EH/EH, Por que sou tão sábio, 3), quer aclarar que o trânsito pelas mais diversas ordenações hierárquicas de impulsos também comporta processos de declínio, desagregação e anarquia. Por isso, de modo enigmático, diz identificar-se ao pai, de constituição frágil e morto precocemente, e, ao mesmo tempo, à mãe que vive e envelhece. E afirma ser essa “dupla ascendência” que o caracteriza o que o autoriza a adotar as perspectivas da ascensão e do declínio, a percorrer do mais alto ao mais baixo “degrau da escada da vida” (Cf. EH/EH, Por que sou tão sábio, 1). Dessa forma, mostra que a décadence também possibilitou a ele um ângulo de visão singular, ainda que restrito.

Não obstante, embora o filósofo considere a enfermidade uma "espécie de décadence” (Cf. EH/EH, Por que sou tão sábio, 1), esclarece por que ter freqüentemente vivenciado o “declínio vital” não o fez um décadent avant la lettre. Em Para Além de Bem e Mal, apresenta a décadence como um processo de anarquização ${ }^{39}$ dos impulsos: “a corrupção

\footnotetext{
${ }^{39}$ Müller-Lauter comenta que a caracterização da décadence, feita por Paul Bourget no primeiro volume dos Essais de Psychologie Contemporaine (1888), impressionou Nietzsche: “Bourget explica a décadence enquanto processo pelo qual se tornam independentes partes subordinadas no interior de um organismo. Esse processo tem por conseqüência a 'anarquia'” (MÜLLER-
} 
como indicação de que no interior dos instintos ameaça a anarquia, de que se encontra abalado o fundamento dos afetos, a que se chama 'vida'” (JGB/BM, 258). Segundo o filósofo, a anarquia ocorre quando, no decorrer da luta, todos os impulsos querem o domínio absoluto. Nesses casos, como estratégia de autoconservação, um único impulso ou conjunto de impulsos faz-se tirano, para compensar a falta de organização do conjunto ${ }^{40}$. A partir disso, conclui que não são necessariamente doentios, décadents, os que vivenciam uma enfermidade, mas os que padecem de uma desagregação das ordenações hierárquicas de impulsos e, por isso, adotam uma única perspectiva, um só ponto de vista. Sendo assim, é por ser caracterizado pelo maior dinamismo dos impulsos, pelo revezamento das relações

LAUTER, 1999, p.12). Segundo ele, Nietzsche, ao examinar o estilo musical de Wagner, ao perceber que cada andamento é particularizado, e tenta tornar-se soberano, ao constatar que a subordinação entre as partes mostra-se aleatória, compondo uma obra fragmentária, passa a caracterizá-lo como décadent. Nesse caso, o expediente encontrado foi o "expressivo a qualquer preço”, para compensar o falta de organização (Cf. MÜLLER-LAUTER, 1999, p.13-15). Com isso, para o filósofo, Wagner é tirano por conta de seu pathos, presente em seu estilo musical, assim como Sócrates é tirano através da dialética de sua razão, fundada na moral. Destarte, para o comentador, "Pode-se descrever a décadence como perda da capacidade de organização. Segue-se daí desorganização ou desagregação de uma pluralidade reunida num todo: desagregação de uma estrutura posta em ordem” (Müller-Lauter, 1999, p.24). Cf: MÜLLER-LAUTER, 1999. p.11-30.

${ }^{40}$ No Crepúsculo dos Ídolos, Nietzsche explica que a anarquia dos impulsos conduz à tirania de muitos, fazendo-se assim necessário descobrir um contratirano mais forte. Ao apresentar o problema de Sócrates, revela que, nesse caso, foi a razão que se fez tirana: "Ser racional foi de rigueur, foi o seu último remédio (...) Estava-se em risco, só se tinha uma escolha: ou perecer, ou ser absurdamente racional...” (GD/CI, O problema de Sócrates, 10). Segundo ele, para um tipo décadent, a precedência da razão surge como um remédio, um artifício pessoal de autoconservação, ante a anarquia instintual. Assim, quando apresenta Sócrates como um “mal-entendido”, a doença diagnosticada é a racionalidade a todo preço: "a vida clara, fria, cautelosa, consciente, sem instinto, oferecendo resistência aos instintos era, ela mesma, apenas uma doença, uma outra doença - e de modo nenhum um caminho de retorno à 'virtude', à 'saúde', à felicidade... Ter de combater os instintos - eis a fórmula para a décadence: enquanto a vida se intensifica, a felicidade é igual a instinto" (GD/CI, O problema de Sócrates, 11). Sócrates, saudável aos olhos de seus contemporâneos, padecia de uma debilitação na dinâmica de impulsos, o impulso racional era superexcitado, enquanto os demais eram combatidos: "Em Sócrates, a desertificação e a anarquia estabelecida no interior dos instintos não são os únicos indícios de décadence: a superfetação do lógico e aquela maldade de raquítico que o distinguem, também apontam para ela” (GD/CI, O problema de Sócrates, 4). 
de mando e obediência, que pode se considerar como summa summarum sadio e décadent apenas como ângulo, especialidade (Cf. EH/EH, Por que sou tão sábio, 2).

Além disso, no Crepúsculo dos Ídolos, alerta que a anarquia de impulsos ocorre quando, em episódios de declínio vital, não se sabe “escolher” o melhor para si: “eu não sei encontrar o que é mais proveitoso para mim’... Desagregação dos instintos!” (GD/CI, Incursões de um Extemporâneo, 35). Por esse viés, nunca foi doentio, pois sempre conseguiu, em momentos de baixa vitalidade, encontrar seu remédio mais apropriado para impedir a desagregação de impulsos, fazer oposição à décadence, "defender-se” dela ${ }^{41}$. Com efeito, enquanto um décadent não sabe selecionar o que lhe convém, um homem "bem logrado" age segundo um "princípio seletivo", sabe escolher o que lhe é mais apropriado e abandonar, deixar de lado o que lhe é pernicioso:

Está sempre em sua companhia, quer esteja com livros, homens, ou paisagens: honra ao escolher, ao abandonar, ao confiar. Reage a todos os estímulos lentamente, com aquela lentidão que uma longa cautela e um orgulho proposital aprimoraram nele - examina o estímulo que se aproxima dele, está longe de ir ao seu encontro. Não acredita nem em "infelicidade" nem em "culpa": fica quite consigo, com outros, sabe esquecer - é forte o bastante para que tudo tenha de lhe sair da melhor maneira - Pois bem, eu sou o reverso de um décadent: pois acabo de me descrever (EH/EH, Por que sou tão sábio, 2)

\footnotetext{
${ }^{41}$ Em O caso Wagner, admite: "Muito bem! Tanto quanto Wagner, eu sou um filho desse tempo: quer dizer, um décadent: mais eu compreendi isso, e me defendi. O filósofo em mim se defendeu”.(WA/CW, Prólogo). Ora, o "filósofo" que em Nietzsche que se defendeu é, pois, o próprio corpo. Foi o corpo o que ditou o "princípio seletivo" para escolha dos "remédios", das restrições necessárias e das condições de vida. Com isso, o filósofo mostra que sua "defesa” da limitação perspectiva se deu no âmbito do dinamismo de impulsos. Em última análise, foi sempre "instintivamente" que fez as suas "escolhas”, afinal, a consciência mesma não está para além de um efetivar-se de impulsos. Em Para Além de Bem e Mal, Nietzsche esclarece: “'estar consciente’ não se opõe de algum modo decisivo ao que é instintivo - em sua maior parte, o pensamento consciente de um filósofo é secretamente guiado e colocado em certas trilhas pelos seus instintos” (JGB/BM, 3).
} 
Desta forma, se as índoles doentias, escolhem os remédios errados, ao contrário, as saudáveis, ante as adversidades, instintivamente, sempre escolhem os remédios que lhe são mais apropriados. No contexto de sua autobiografia, Nietzsche vê como sintomas de sua saúde suas escolhas de alimentação, clima, moradas, recreações e companhias. De igual modo, apresenta como sintoma de sua “índole bem lograda” a cautela de não reagir imediatamente a um estímulo nocivo, associada a sua capacidade de esquecer-se rapidamente do que lhe afetou.

Nietzsche nomeia de “fatalismo russo" essa capacidade de não-reação imediata a um estímulo: “aquele fatalismo sem revolta, com o qual o soldado russo para quem a campanha torna-se muito dura finalmente deita-se na neve. Absolutamente nada mais em si aceitar, acolher, engolir - não mais reagir absolutamente...” (EH/EH, Por que sou tão sábio, 6). Ao ver do filósofo, numa situação adversa, da qual não é possível livrar-se no momento, o melhor remédio é não reagir, quando uma reação produziria um rápido consumo de energia nervosa e um aumento de bílis no estômago ${ }^{42}$. Ele conta que quando vivenciou estados de doença e fraqueza, contra os impulsos do ressentimento, o revolver venenos, o aborrecimento, a impotência, a sede de vingança, ao invés de revoltar-se, tomou o cuidado de não desperdiçar suas forças em fins negativos, evitando o empobrecimento supérfluo do instinto de autodefesa (Cf. EH/EH, Por que sou tão esperto, 8). Relata ainda que conseguiu lutar contra os sentimentos de vingança e rancor através do esquecimento, evitando que suas lembranças calassem fundo demais e se tornassem “uma ferida suporante”.

Na segunda dissertação da Genealogia da Moral, apresenta a capacidade do esquecimento como própria de uma "saúde forte” e discorre sobre suas vantagens:

\footnotetext{
42 Pelo mesmo viés, no Crepúsculo dos Ídolos, apresenta como sintoma de décadence a incapacidade de sustentar uma oposição a um estímulo: “o 'precisa-se reagir' segue-se a cada impulso. Em muitos casos, uma tal necessidade já é prova de um caráter doentio, de decadência, de um sintoma de esgotamento" (GD/CI, O que falta aos alemães, 6).
} 
Fechar temporariamente as portas e janelas da consciência; permanecer imperturbado pelo barulho e luta do nosso submundo de órgãos serviçais a cooperar e divergir; um pouco de sossego de tabula rasa da consciência, para que novamente haja lugar para o novo, sobretudo para as funções e os funcionários mais nobres, para o reger, prever, predeterminar (pois nosso organismo é disposto hierarquicamente) - eis a utilidade do esquecimento, ativo, como disse, espécie de guardião da porta, de zelador da ordem psíquica, da paz, da etiqueta: com o que logo se vê que não poderia haver felicidade, jovialidade, esperança, orgulho, presente, sem o esquecimento (GM/GM, II, 1).

Esclarece que o homem no qual essa capacidade está comprometida pode ser comparado a um dispéptico, pois esse nada consegue ‘dar conta’. No seu caso, através da atividade do esquecimento, conseguiu melhor digerir suas vivências, livrar-se mais facilmente de uma impressão recebida, evitando o azedume de um rancor. Portanto, associados, "fatalismo russo” e capacidade para o esquecimento foram os principais remédios que lançou mão para combater o ressentimento ${ }^{43}$, infelizmente, a mais natural inclinação do enfermo.

Destarte, é por ter uma grande saúde, por ter adotado até mesmo a óptica da décadence e não ter se atido a ela, que Nietzsche afirma ter para os sintomas de ascensão e declínio um faro mais refinado do que jamais teve um homem: "sou mestre par excellence nisso - conheço a ambos, sou ambos” (EH/EH, Por que sou tão sábio, 1). Ao ter adotado perspectivas ascendentes e declinantes, mais abrangentes e mais restritas, ele fez dessas

\footnotetext{
${ }^{43}$ Assoun investiga a caracteriologia do ressentimento que Nietzsche delineia ao longo das três dissertações da Genealogia da Moral. Destaca que Nietzsche coloca a reatividade primária e o superdesenvolvimento mnésico como os principais traços de caráter do ressentido. A nosso ver, isso explica por que o filósofo considera a capacidade de não reagir imediatamente ao estímulo e a atividade do esquecimento sintomas de saúde. Cf. ASSOUN, P-L. Freud et Nietzsche. Paris, Presses Universitaires de France, 1980.
} 
experimentações o pressuposto de sua psicologia ${ }^{44}$. Afinal, foi em períodos de décadence que aprimorou sua aptidão para a arte da observação de sintomas, refinando seu olhar psicológico:

Preciso dizer, depois de tudo isso, que em questões de décadence sou experiente? Soletrei-a de trás para frente e de frente para trás. Mesmo aquela arte de filigrana do captar e conceber em geral, com aqueles dedos para nuances, aquela psicologia do "ver-atrás-da-esquina”, e tudo mais que me é próprio foi aprendido somente naquele tempo, é propriamente o presente daquele tempo, em eu tudo em mim se refinava, a observação mesma com todos os órgãos de observação (EH/EH, Por que sou tão sábio, 1)

Sendo assim, foi somente por ter vivenciado episódios de décadence, experimentado pensamentos que daí podem emergir que Nietzsche consegue deslocar seu olhar para outras filosofias e, a partir delas, detectar sintomas de um corpo doente. Portanto, é apenas por ter adotado a perspectiva da décadence que consegue desvendar a psicologia dos grandes nomes da tradição filosófica, “a história escondida dos filósofos” (EH/EH, prólogo, 3). Em suma, é somente por estar autorizado por sua grande saúde que, no contexto de sua tarefa

\footnotetext{
${ }^{44}$ Em Para Além de Bem e Mal, Nietzsche apresenta o campo de ação reservado ao psicólogo: “A alma humana e suas fronteiras, a amplitude até aqui alcançada nas experiências humanas interiores, as alturas, profundezas e distâncias dessas experiências, toda a história da alma até o momento, e as suas possibilidades inexauridas: eis o território de caça reservado para o psicólogo nato e amigo da “caça grande”" (JGB/BM, 45). Ainda nessa obra, ao apresentar a ousadia de sua expedição psicológica, a de descer às profundezas da alma humana, adentrar nesse "quase inexplorado reino de conhecimentos perigosos", adverte: "Se o seu navio foi desviado até esses confins, muito bem: Cerrem os dentes! Olhos abertos! Mão firme no leme! - navegamos diretamente sobre a moral e além dela, sufocamos, esmagamos talvez nosso próprio resto de moralidade, ao ousar fazer a viagem até lá - mas que importa nós! Jamais um mundo tão profundo de conhecimento se revelou para navegantes e aventureiros audazes (...)” (JGB/BM, 23). Novamente, Nietzsche recorre às figuras do caçador, navegante e aventureiro como emblemáticas de seu experimentalismo. Agora, as usa para esclarecer que suas experimentações de diferentes modos de pensar são o pressuposto de sua tarefa psicológica.
} 
crítica, pode lançar mão de seu refinado faro psicológico para diagnosticar quais índoles de corpo se escondem "por trás” das filosofias.

No prefácio de A Gaia Ciência, diz que uma das questões mais atraentes para um psicólogo ${ }^{45}$ é a da relação entre saúde e filosofia. Ao direcionar sua “curiosidade científica” para seus próprios episódios de doença, percebeu que eles serviram de oportunidade de autoquestionamento e auto-experimentação com o pensar. Com efeito, foi ao debruçar-se sobre sua própria enfermidade que pode responder ao questionamento que mais interessa a um psicólogo: “- o que será do pensamento mesmo, que é posto sob a pressão da doença”

${ }^{45}$ Apesar de sua diversidade, as psicologias do século XIX recorreram às ciências da natureza, na tentativa de encontrar a explicação dos processos psíquicos. As psicologias, através dessa busca por cientificidade, visavam se contrapor à psicologia racional, que encontrava seu pressuposto na noção metafísica de alma. Para tanto, operaram uma redução dos processos psíquicos aos fenômenos orgânicos. Nietzsche, como um filho de seu tempo, também se dedicou aos estudos de fisiologia, medicina e ciências da natureza (Cf. EH/EH. Humano demasiado humano, 3). Quando se interessou pela psicologia experimental nascente, acreditou haver encontrado uma aliada no combate à metafísica. A seu ver, direcionar o olhar para o corpo e tomá-lo como berço dos pensamentos era contrapor-se a toda uma tradição filosófica que havia edificado a concepção de humano a partir de uma alma, separada do corpo, num "puro espírito", uma res cogitans, enquanto agente e causa de todo pensar. Andler afirma que o filósofo se alegrou ao encontrar aliados na jovem psicologia positiva francesa, que também procurava dissipar o fantasma da consciência una, da noção de alma substancial. Ele comenta que o filósofo tomou contato com as obras Maladies de la personnalité (1885) de Th. Ribot, e Des sociétés animales (1877) de A. Espinas. Na mesma direção, Haaz, em seu artigo Nietzsche, Ribot et les conditions biologiques de l'esprit, defende que Nietzsche tomou conhecimento da Revue philosophique de la France e de l'étranger, fundada por Ribot, pois a ela fez menção em algumas de suas correspondências de 1887, a Paul Rée e Malwida von Meysenburg. A partir disso, o comentador procura na filosofia de Nietzsche as principais influências do pensamento, não apenas de Ribot, mas de outros pensadores que publicavam na Revue (como Espinas, Roux, Hartmann...). De modo geral, Haaz comenta que Nietzsche apreende da escola positivista a idéia de que os organismos são sociedades de seres vivos ínfimos e aglomerados. Da influência do pensamento de Ribot, destaca que o biólogo explica às funções psíquicas seguindo dois eixos: evolução e dissolução. A "incoordenação, instabilidade” é a causa da doença e, por inversão, a "coordenação" e "estabilidade” do aparelho psicofísico são as condições fundamentais da saúde. Nietzsche, de igual modo, lança mão dos movimentos de coordenação e desagregação dos impulsos para apresentar o que entende por saúde e doença. Para ele, se na doença há oscilação contínua dos impulsos e a falta de um centro de gravidade, na saúde, há uma direção clara e precisa. Cf. HAAZ, I. Nietzsche, Ribot et les conditions biologiques de l'esprit. Collection Epistémologie et Philosophie des Sciences, l’Harmattan, 2002 \& ANDLER, C. 1958. 
(FW/GC, Prefácio, 2). A partir disso, ele considera que seu maior aprendizado adquirido com a doença foi o poder olhar de modo mais refinado para tudo o que foi filosofado até então:

Adivinha-se melhor que antes os involuntários descaminhos, ruas laterais, lugares de repouso, lugares de sol do pensamento, a que os pensadores que sofrem, precisamente como sofredores, são conduzidos e seduzidos, sabe-se doravante para onde, inconscientemente o corpo doente, com suas necessidades, impele, empurra, atrai o espírito - em direção ao sol, quietude, brandura, paciência, medicamento, refrigério em qualquer sentido (FW/GC, Prefácio, 2)

Nietzsche relata que também se entregou de "corpo e alma” à doença, mas conseguiu “despertar”: Através dessas experimentações, descobriu que são vários os caminhos abertos pela doença, que são diversas as direções apontadas pelo sofrimento. Ao examinar seu próprio caso, percebeu que foi a sua saúde o que evitou que se perdesse nos caminhos da metafísica. A partir disso, supõe que são os pensadores doentes que preponderam na história da filosofia. Estes, ao invés de fazerem de sua doença oportunidade de experimentação, enveredam-se pelos caminhos que julgam serem mais "fáceis”, os já desbravados ${ }^{46}$.

Assim, em sua análise diagnóstica, pautado na pressuposição de que as formas como se ordenam hierarquicamente os impulsos se mostram, de algum modo “aparecem”, na

\footnotetext{
${ }^{46}$ No prefácio ao segundo volume de Humano Demasiado Humano, após analisar os caminhos filosóficos que trilhou, apresenta o que entende por doença: “Doença é, em todo caso, a resposta, quando queremos duvidar de nossos direitos à nossa tarefa - quando começamos em algum ponto a tornar as coisas mais fáceis para nós. Curioso e terrível ao mesmo tempo! Nossas facilidades são aquilo por que temos que pagar mais duramente! E se queremos depois, retornar á saúde, não nos resta nenhuma escolha: temos de nos carregar mais pesadamente do que jamais estivemos carregados antes” (VM/OS, prefácio, 4).
} 
enunciação dos pensamentos, sentimentos e quereres, afirma serem sintomas de um corpo doente todos os “ousados disparates da metafísica”:

Toda filosofia que coloca a paz mais alto do que a guerra, toda ética com uma concepção negativa do conceito de felicidade, toda metafísica e física que conhecem um termo final, um estado terminal de qualquer espécie, todo preponderante desejo estético e religioso por um à- parte, um além, um fora, um acima, permite que se pergunte se não foi a doença que inspirou o filósofo. $O$ inconsciente travestimento de necessidades fisiológicas sob os mantos do objetivo, do ideal, do puramente espiritual, chega até o aterrorizante - e com bastante freqüência eu me perguntei se, calculando por alto, a filosofia até agora não foi, em geral somente uma interpretação do corpo e um malentendido sobre o corpo (FW/GC, prólogo, 2).

Detecta que a precedência do “espiritual”, característica do racionalismo metafísico, é um sintoma da debilitação na dinâmica de formação de diferentes ordenações hierárquicas. Diagnostica que toda filosofia que deprecia a guerra traduz um esmorecimento na luta de impulsos, que toda ética com uma “concepção negativa” do conceito de felicidade sinaliza um processo de resistência aos instintos, que todo finalismo e teleologia é sinal da necessidade de pôr termo ao combate, e que o desejo de um “para além” dos processos efetivos é sintoma de um corpo em vias de desagregação e perecimento.

Todavia, se, em sua psicologia, Nietzsche considera que são os pensamentos, como sintomas de determinados corpos, o que permite diagnosticar as formas como se processam as relações de mando e obediência, estabelecidas no decorrer da luta de impulsos, no contexto genealógico, toma as valorações morais como o melhor testemunho das ordenações hierárquicas de impulsos que caracterizam um filósofo: “(...) particularmente a sua moral que dá um decidido e decisivo testemunho de quem ele é - isto é, da hierarquia em que se dispõem os impulsos mais íntimos da sua natureza” (JGB/BM, 6). Em outro 
parágrafo da mesma obra, afirma que as morais não passam de uma "semiótica dos afetos (Zeichensprache der Affekte)" (JGB/BM, 187), que serve para indicar os expedientes daquele que valora (JGB/BM, 187). Nessa mesma direção, no Crepúsculo dos Ídolos, assevera que a moral é unicamente um discurso de signos, uma sintomatologia, e que é preciso saber do que se trata para tirar algum proveito dela (GD/CI, Os “Melhoradores” da Humanidade, 1). Assim, vemos que no registro genealógico, o filósofo colore sua psicologia com o matiz do valor, apresentando as valorações como sintomas privilegiados para diagnosticar a necessidade de um corpo:

Quais os grupos de sensações que dentro de uma alma despertam mais rapidamente, tomam a palavra, dão as ordens: isso decide a hierarquia inteira de seus valores, determina por fim sua tábua de bens. As valorações de uma pessoa denunciam algo da estrutura de sua alma, e aquilo em que ela vê suas condições de vida, sua autêntica necessidade (JGB/BM, 268).

De modo mais preciso, Nietzsche não apenas considera as estimativas de valor sintomas de ordenações hierárquicas de impulsos, mas, mais do que isso, esclarece que elas emergem em resposta a uma específica demanda de corpo. Por esse viés, para ele, tomar a moral como problema ${ }^{47}$ é considerar as valorações um expediente a uma necessidade vital que, sub-repticiamente, se impõe; é ter em vista que mesmo “por trás de toda lógica e de sua

\footnotetext{
${ }^{47}$ No quinto livro de A Gaia Ciência, no parágrafo intitulado Moral como problema, Nietzsche já denunciava a insuficiência da "história genética dos sentimentos e estimativas de valor" dos psicólogos e historiadores da moral, e apresentava o alcance de sua tarefa filosófica: "Ninguém, portanto, examinou até agora o valor dessa mais célebre de todas as medicinas, chamada moral: para o que é preciso, primeiro de tudo, alguma vez... - pô-lo em questão. Pois bem! Essa é justamente nossa obra. -" (FW/GC, V, 345). Não obstante, é, sobretudo, na Genealogia da Moral que o filósofo, ao se questionar sobre o valor dos valores, procura levar a termo esse intento expondo os meandros da moral cristã. Aqui, na figura de um tipo, o sacerdote ascético, a moralidade cristã aparece como medicamento para combater a anarquia e a autodissolução que ameaçam o rebanho doente, no qual aquele mais perigoso dos explosivos, o ressentimento, é continuamente acumulado (Cf. GM/GM, III, 15).
} 
aparente soberania de movimentos existem valorações, ou, falando mais claramente, exigências fisiológicas para a preservação de uma determinada espécie de vida” (JGB/BM, 3).

Destarte, na Genealogia da Moral, ao se questionar sobre o valor dos valores, Nietzsche apresenta a moral como um sintoma, mas também como um medicamento para o tipo homem (Cf. GM/GM, prólogo, 6). Com isso, o filósofo aclara que as estimativas de valor apenas são úteis ao genealogista quando remetidas às necessidades do tipo que as impôs. Por isso, no âmbito do procedimento genealógico, deixa claro que seu olhar diagnóstico será sempre direcionado para as condições e circunstâncias nas quais tais valorações emergiram:

Enunciemo-la, esta nova exigência: necessitamos de uma crítica dos valores morais, o próprio valor desses valores deverá ser colocado em questão - para isso é necessário um conhecimento das condições e circunstâncias nas quais nasceram, sob as quais se desenvolveram e se modificaram (moral como conseqüência, como sintoma, máscara, tartufice, doença, mal-entendido, mas também moral como causa, medicamento, estimulante, inibição, veneno), um conhecimento tal como até hoje nunca existiu nem foi desejado (GM/GM, prólogo, 6).

Desse modo, ao apresentar a moral como sintoma de um tipo, também capaz de apontar seus expedientes, Nietzsche inscreve a sintomatologia e a tipologia em sua crítica genealógica $^{48}$. Em seu quadro tipológico, elenca os tipos doentios, décadents, como aqueles que padecem de uma desagregação hierárquica de impulsos e, devido a isso,

48 Deleuze esclarece que, na tipologia nietzschiana, o que caracteriza o tipo hegemônico é o "espírito de vingança”, que: “longe de ser um traço psicológico, o espírito de vingança é o princípio do qual nossa psicologia depende” (DELEUZE, 1970, p.39). Ele aclara que, no final de sua empreitada genealógica, Nietzsche conclui que foi o "impulso" de vingança que tomou precedência e acabou por constituir tout court nossa psicologia. Cf. DELEUZE, G. 1970. 
lançam mão de toda sorte de expedientes para não perecerem. A exemplo disso, no Crepúsculo dos Ídolos, mostra que a anarquia de impulsos pode se travestir de um conjunto valorativo absurdamente racional, formulado a partir da equação razão $=$ virtude $=$ felicidade. Nesses casos, ante a desagregação instintual, o remédio “escolhido” pelo tipo foi a superexcitação de um único impulso, o racional. Pelo mesmo prisma, apresenta os tipos dotados de uma grande saúde como aqueles que conseguem levar suas experiências arrojadas e dolorosas mais longe, suplantando até mesmo o impulso de autoconservação ${ }^{49}$, pois eles “amam servir-se de experimento num sentido novo, talvez mais amplo, talvez mais perigoso” (JGB/BM, 210). Caracterizados pela imposição temporária de diferentes ordenações hierárquicas de impulsos, sem necessitarem recorrer ao impulso “tirânico” da razão e à adoção do conjunto de valores que lhe concerne, conseguem ousar a criação de valores outros.

Não obstante, Nietzsche não se contenta em remeter as estimativas de valor aos tipos, recusando sua origem metafísica. Ele procura ainda expor a significação do medicamento que os homens, diante das sendas abertas pelo sofrimento, acabam por recorrer. Com efeito, ao perscrutar a relação do “animal homem” com seu sofrimento, percebe que para os décadents "o sofrimento é sempre lembrado como o primeiro argumento contra a existência” (GM/GM, II, 7). Embora o sofrimento que, inevitavelmente emerge da luta de impulsos, possa receber vários sentidos, os que padecem de uma desagregação de impulsos maldizem o corpo, lamentam sua finitude, olham com repulsa suas mudanças. De modo mais preciso, o homem, ao necessitar de um sentido a seu

\footnotetext{
${ }^{49}$ Em Para Além de Bem e Mal, Nietzsche alerta: “os fisiólogos deveriam prestar mais atenção, ao estabelecerem o impulso de autoconservação como impulso cardinal de um ser orgânico (...) aqui, como por toda parte, cuidado com princípios teleológicos supérfluos!” (JGB/BM, 13). De acordo com o filósofo, o impulso de autoconservação não é o móbil da luta de impulsos. De modo mais preciso, a luta não caminha para tal fim. Embora tal impulso irrompa com freqüência, é apenas um dos que podem tomar precedência no combate.
} 
sofrimento, acabou por encontrar na recusa ao mundo efetivo uma resposta ${ }^{50}$. Contudo, apesar de ter encontrado um sentido ao “para-quê do sofrimento” no além mundo, em um domínio que não o da efetividade, ao mesmo tempo, devido a um estratagema de conservação, o homem procura de todo modo postergar seu aniquilamento. Concomitantes, a recusa aos processos efetivos e a incapacidade de furtar-se a eles, consegue preservar essa configuração fisiopsicológica, que é o homem, mas o torna um animal doente (Cf. GM/GM, II, 24). Destarte, malgrado esse expediente oferecer um sentido ao sofrer, traz conjuntamente um novo sofrimento "mais profundo, íntimo, corrosivo": faz o homem debelar seus impulsos.

De outro modo, para os tipos da grande saúde, mesmo o sofrer não conduz a um mal-estar em relação aos processos efetivos, ao contrário, pode significar a abertura para a criação de outros sentidos e valores ${ }^{51}$. Nietzsche entende que o sofrimento pode auxiliar na

\footnotetext{
${ }^{50}$ Na Genealogia da Moral, no conjunto de sua análise da psicologia do cristianismo, Nietzsche nomeia essa "rebelião contra os mais fundamentais pressupostos da vida" de ideal ascético. Na terceira dissertação, apresenta o problema da significação desse ideal e sua relação com o sofrimento humano: "Isto justamente significa o ideal ascético: que algo faltava, que uma descomunal lacuna circundava o homem - ele não sabia justificar a si mesmo, explicar-se, afirmarse, ele sofria com o problema de seu sentido” (GM/GM, III, 28). Assim, o homem, para não resvalar em um "niilismo suicida", encontrou no ideal ascético faute de mieux um sentido a seu sofrimento. Desse modo, esse ideal serviu como expediente para um tipo que, em "declínio vital”, na iminência de uma desagregação de impulsos, necessitou de um artifício de autoconservação. Com efeito, o ideal ascético "brota do instinto de proteção e de cura de uma vida em degeneração, que por todos os meios procura manter-se e combater por sua existência: é indício de uma parcial obstrução fisiológica e cansaço, contra os quais os mais profundos instintos da vida, que permaneceram intactos, combatem sem descanso com novos meios e invenções” (GM/GM, III, 13). Mas, embora o ideal ascético preserve o tipo, ofereça a ele uma resposta, um sentido a seu sofrimento, o interdito do suicídio lançado pelo cristianismo, ao impedi-lo de escapar ao mundo efetivo, aqui o mantém em um minimum vital. Por isso, Nietzsche diz que tal expediente gerou um sofrimento maior ao humano, o da culpa. Jogado no mundo, o homem não pode lançar mão de seus instintos, ressentido de sua condição, encontra o culpado de seus males em seu próprio livrearbítrio.

${ }^{51}$ Em Para Além de Bem e Mal, Nietzsche defende "Quereis, onde possível - e não há nenhum 'onde possível' mais maluco -, abolir o sofrimento; e nós? - parece, precisamente, que nós o preferimos ainda o superior e pior que jamais foi! Bem-estar, como vós o entendeis - isso nem
} 
descarga de impulsos “animais”, que foram “dominados” no processo de formação da consciência $^{52}$. Acreditando que sua liberação gera um fortalecimento do homem, ele critica os que vêem as “propensões naturais” com maus olhos. Detecta sintomas de décadence em todas as aspirações ao além-mundo, na recusa à natureza, aos instintos, ao animal (Cf. GM/GM, II, 24). Assim, para fazer frente à décadence que vê preponderar em seu tempo, propõe ao homem do futuro realizar um “ensaio inverso”: irmanar todas as suas propensões que foram desnaturadas. Contudo, afirma que para tal intento:

sequer é um alvo, para nós parece-nos o fim! Um estado que logo torna os homens ridículos e desprezíveis - que faz desejar que sucumbam! A disciplina do sofrimento, do grande sofrimento não sabeis que somente essa disciplina criou todas as elevações do homem até agora?” (JGB/BM, 225). Dentre as vantagens do sofrimento, ressalta a inventividade em utilizar a infelicidade em benefício próprio, a tensão que faz crescer a força e a bravura para ir ao fundo de si mesmo. Vale dizer que embora Nietzsche não recuse o sofrimento, não faz deste o móbil para a ação do homem. A nosso ver, o filósofo não é um apologista dos estados mórbidos. Ao contrário, ele é um crítico daqueles que encontram no prazer e na dor a explicação das ações morais (Cf. JGB/BM, 225). Com efeito, é precisamente esse o teor de sua crítica aos psicólogos utilitaristas ingleses (Bentham e Stuart Mill). A seu ver, estes associam felicidade à ausência de dor, e infelicidade à privação do prazer. De outro modo, para Nietzsche, prazer e dor emergem da luta de impulsos. Por isso, longe de serem fatores explicativos das ações humanas, são "estados anexos”, “acessórios” (Cf. JGB/BM, 225). Portanto, se Nietzsche toma partido do sofrimento é porque, ao procurar afirmar a efetividade em todos os seus aspectos, não poderia deixar de fazê-lo. Além disso, de acordo com seu pensamento, de nada valeria dizer ao homem buscar o sofrimento. Inerente a luta de impulsos, ele é inevitável.

${ }^{52}$ Como vimos, no processo de formação da consciência, grande parte dos impulsos “animais” foi dominada. Quando o homem se viu aprisionado na opressiva estreiteza e moralidade dos costumes, a impossibilidade de "descarregar para fora” seus "velhos instintos" engendrou a má-consciência. Nietzsche a considera a mais profunda doença que o homem teve de contrair sob a pressão da mudança que teve que passar, para viver no âmbito da sociedade e da paz: "a hostilidade, a crueldade, o gosto pela perseguição, pelo assalto, pela mudança, pela destruição - tudo isso se voltando contra os possuidores de tais instintos: essa é a origem da 'má consciência'” (GM/GM, II, 16). Ele acredita que, com ela, foi introduzido o maior e mais inquietante adoecimento, do qual a humanidade até hoje não convalesceu, o sofrimento do homem consigo mesmo. Contudo, como tais instintos permaneceram em estado de latência, não deixaram de fazer suas exigências. Por isso, o filósofo diz que a má-consciência é uma doença, tal como a gravidez é uma doença. A possibilidade de tais impulsos novamente tomarem precedência, faz do homem um enigma e uma promessa de futuro (GM/GM, II, 16; 19). 
Seria necessária, para aquele alvo, uma outra espécie de espíritos, do que precisamente neste século, são verossímeis: espíritos fortalecidos por guerras e vitórias, aos quais a conquista, a aventura, o perigo, até mesmo a dor, se tornaram necessidade; para isso seria necessário o hábito do ar cortante das alturas, de andanças de inverno, de gelo e montanhas em todos os sentidos; para isso seria necessária uma espécie de sublime maldade mesmo, uma última malícia do conhecimento, muito segura de si, que faz parte da grande saúde; seria necessária, em suma, e é pena, justamente essa grande saúde!... (GM/GM, II, 24)

Com efeito, o filósofo aspira a um "espírito criador" que seja capaz de, em um tempo vindouro, fazer diferentes ensaios, experimentar outras formas de valorar, criar novas "tábuas de valores”, que não mais expressem um profundo mal-estar com os processos efetivos. Espera a vinda de homens dotados de grande saúde que possam livrar a efetividade da "maldição" deposta sobre ela (Cf. GM/GM, II, 24). Até chegar esse momento, ele mesmo, como um tipo da grande saúde, quer a partir da exposição de sua trajetória de experimentações, abrir caminhos para outras e inúmeras possibilidades de criação de valores, que sejam afirmativos em relação aos processos dinâmicos da efetividade. 


\section{CAPÍTULO III:}

\section{A "medicina filosófica": uma tarefa para um tempo vindouro}

Médico, ajuda a ti próprio: assim ajudas também o teu doente. Seja esta tua melhor ajuda, que ele veja com seus olhos aquele que cura a si próprio.

(NIETZSCHE)

Quando Nietzsche afirma a necessidade de tipos sadios para a criação de novos valores no futuro, faz com que o problema da saúde adquira relevância filosófica. Com efeito, no prefácio de A Gaia Ciência, o filósofo diz estar à espera de um “médico filosófico" que arrisque a proposição de que todo filosofar se trata de "saúde, futuro, crescimento, potência, vida...” (FW/GC, Prefácio, 2). Em Ecce Homo, ao relatar sua trajetória filosófico-vivencial, mostra como se deu o processo de criação de uma filosofia por um tipo dotado de grande saúde, atento às “disposições fundamentais da própria vida” (EH/EH, Por que sou tão esperto, 10). Apresenta o modo como estabeleceu relações consigo mesmo e com as pessoas, como conseguiu vencer sua ignorância in physiologicis, adequando sua “dieta espiritual” aos períodos do dia. Diz que aprendeu a se alimentar, respeitando o "tamanho do próprio estômago" (EH/EH, Por que sou tão inteligente, 1). Conta que sempre esteve atento às variações climáticas e meteorológicas, à escolha dos lugares corretos a seu metabolismo. Fala da importância do combate ao imobilismo e à vida sedentária. Discorre sobre suas distrações, sobre seu trato com os livros e com a música. E assim, a partir da exposição de suas experiências, dá um exemplo de como pensar a saúde a partir de outros critérios, mais afirmativos em relação ao corpo e aos processos efetivos.

Ainda em Ecce Homo, Nietzsche esclarece que o desprezo ao corpo é fruto da elevada importância dada a conceitos, a partir dos quais a tradição metafísica procurou atestar a "divindade” do homem. A seu ver, a metafísica inventou larga trama conceitual para caluniar a efetividade, como “Deus”, “além”, “mundo verdadeiro”, e para desvalorizar 
o corpo: “a noção de 'alma’, ‘espírito’, por fim ‘alma imortal’, inventada para desprezar o corpo, torná-lo doente - 'santo’” (EH/EH, Porque sou um destino, 8). Essas noções nos levaram a tratar com frivolidade todas as coisas que na vida merecem seriedade, “as questões de alimentação, habitação, dieta espiritual, assistência a doentes, limpeza, clima!” (EH/EH, Porque sou um destino, 8). Destarte, na exposição de sua trajetória filosóficovivencial, ressalta a importância das pequenas coisas que ao juízo comum são consideradas insignificantes: “alimentação, lugar, clima, recreação, a inteira casuística do amor próprio” (EH/EH, Por que sou tão esperto, 10). Ao julgar que essas coisas cotidianas são mais importantes do que tudo que se deu importância até agora, acredita que também em questões de política, ordem social e educação, precisamos aprender de outro modo, reaprender (Cf. EH/EH, Por que sou tão esperto, 10).

Na filosofia nietzschiana, o médico aparece como a imagem daquele que faz o diagnóstico da décadence e que, ao curar-se a si mesmo, procura fazer com que o outro tome para si a tarefa de curar-se a si próprio. Em seus escritos de caráter autobiográfico, Nietzsche conta que ao se colocar como "médico e doente em uma pessoa", se coagiu a um inexperimentado “clima da alma”, elaborou uma “dietética e disciplina” para, em momentos de sofrimento, vencer a luta contra o ressentimento, o pessimismo do cansaço de viver (Cf. VM/OS, prefácio, 5). Através disso, ele esclarece que em seu processo de restabelecimento e cura não permaneceu inerte. Ele se tomou nas mãos, não se deixou medicar com remédios errados. Criou meios de cura contra danos, utilizou os acontecimentos ruins em sua vantagem, tornou-se mais forte, ao superar o adverso. Procurou escolher o que melhor lhe cabia, respeitando sua "medida do compatível” (Cf. EH/EH, Por que sou tão sábio, 2). Por fim, se decide levar a público suas vivências pessoais é porque está confiante em não ser o único a querer seguir o caminho para uma “nova saúde”, do amanhã e depois de amanhã (Cf. VM/OS, prefácio, 6). 
Na atualidade, os princípios que norteiam nossas práticas médicas se encontram na Constituição da Organização Mundial de Saúde (OMS), na qual a saúde é definida como um "estado de completo bem-estar físico, mental e social, não consistindo apenas na ausência de uma doença ou enfermidade, ${ }^{53}$. A partir deles, entendemos que o homem saudável é aquele que não está enfermo, e que, além disso, se encontra em estado de plena satisfação física, mental e social. Por outra perspectiva, Nietzsche apresenta a saúde não como um estado de ausência de enfermidade e ainda critica os critérios de bem-estar propagados pelos décadents, vinculados à conservação e à manutenção do já instituído Nesse horizonte, acreditamos que o filósofo pode nos ajudar a pensar se, em nossas práticas médicas, ao invés de promovermos a saúde, acabamos por propiciar a décadence, nos levando a refletir se os valores que orientam nossos modos de vida propiciam um efetivo “bem-estar” ou se ainda é extemporâneo o diagnóstico nietzschiano:

Bem-estar, como vós o entendeis - isso nem sequer é um alvo, para nós parecenos o fim! Um estado que logo torna os homens ridículos e desprezíveis - que faz desejar que sucumbam (JGB/BM, 225)

Em nossa argumentação, tomaremos a figura do médico como a imagem daquele que procura outros pressupostos para a medicina em um tempo vindouro, vinculados à possibilidade de ensaio, experimentação e criação de sentidos e valores, orientadores dos modos de vida.

Em nosso ponto de vista, a filosofia nietzschiana, ao apresentar um outro olhar sobre o corpo e redimensionar a concepção de saúde, possibilita uma revisão de nossas atuais práticas médicas. Contemporaneamente, entendemos que um corpo saudável é aquele que

\footnotetext{
${ }^{53}$ Constituição da Organização Mundial da Saúde (OMS/WHO), elaborada na cidade de Nova York e datada de 22 de Julho de 1946.
} 
executa com normalidade todas as suas funções e que a cura do corpo enfermo é o retorno a um estado de saúde prévio. Assim, como consideramos ser a cura o restabelecimento do correto funcionamento de um determinado órgão ou sistema desajustado, as práticas médicas acabam por assumir um viés corretivo e fragmentado. De outro modo, Nietzsche apresenta a grande saúde como a maior mobilização do corpo em ensaio de hierarquias de impulsos, a experimentação de diferentes formas de querer, sentir e pensar e, mormente, criar valores. Por esse outro viés, acreditamos que as práticas de saúde terão por norte a atividade espontânea do corpo, em seu potencial de criação de novas ordenações hierárquicas, que não prescinde nem mesmo dos processos de desagregação, décadence ${ }^{54}$, para seu fortalecimento.

Ao ver do filósofo, se atribuirmos ao corpo um caráter relacional e dinâmico, se considerarmos que a função de um órgão é a resultante de uma "sucessão de processos mais ou menos profundos, mais ou menos independentes um do outro, de subjugamento” (GM/GM, II, 12), não há mais como pensá-la sem vinculá-la a ação do conjunto, pois “mesmo no interior de cada organismo singular não é de outro modo: a cada crescimento essencial do todo, desloca-se também o sentido dos órgãos singulares” (GM/GM, II, 12). Desse modo, se tivermos em vista o caráter relacional dos processos orgânicos, a saúde do corpo será entendida como o potencial de rearranjo do conjunto, de criação de um "novo" ajustamento entre os impulsos ${ }^{55}$. Nesse processo, até mesmo a “morte”, o sacrifício de

54 Müller-Lauter mostra que, por um lado, Nietzsche exige o homem da "grande síntese" (synthetiche Mensch), "que reúne em si o máximo de experiências contrárias, inclusive as da décadence” (MULLER-LAUTER, 1999, p.26), por outro, toma uma posição "negadora e até aniquiladora" da décadence, ao defender que o homem "mais poderoso" é o que separa de seu organismo as partes "sadias" das "degeneradas". Por fim, o comentador conclui que, em seu último ano de atividade, ao se declarar partidário da segunda posição, Nietzsche estreita seu ângulo de visão sobre a utilidade e a vantagem da décadence para a vida bem constituída. Cf: MÜLLERLAUTER, 1999.

55 Canguilhem, em O normal e o patológico, apresenta o conceito de "normatividade biológica”, como a capacidade que o ser vivo tem de instituir normas diferentes, em condições diversas. Para ele, "ser sadio significa não apenas ser normal numa situação determinada, mas ser, também, 
membros intermediários em benefício do conjunto, é parte das condições do progressus efetivo (Cf. GM/GM, II, 12), pois permite que os impulsos tomem outras direções e, com isso, criem novas formas ${ }^{56}$.

Com efeito, a partir de sua concepção de corpo como multiplicidade de impulsos, Nietzsche elege por critério para diagnosticar a saúde e a doença do tipo o dinamismo da luta, em seus processos de ordenação e desagregação hierárquicas. Segundo ele, a saúde é a maior mobilização dos beligerantes na luta, o acirramento do combate, enquanto a doença é seu arrefecimento. Ele acredita que a contradição e a guerra atuam como "atração e estímulo de vida mais” (Cf. JGB/BM, 200). No decorrer desse combate, há muitas “baixas”, desagregação das ordenações hierárquicas de impulsos, mas o que é indicativo de saúde do corpo é a formação de novos escalonamentos e reorganização das fileiras. Assim,

normativo, nessa situação e em outras situações eventuais. O que caracteriza a saúde é a possibilidade de ultrapassar a norma que define o normal momentâneo, a possibilidade de tolerar infrações à norma habitual e de instituir normas novas em situações novas” (CANGUILHEM, 1990, p.158). Pela sua perspectiva, curar significa criar para si novas normas vitais, às vezes superiores às antigas (Cf. CANGUILHEM, 1990, p.188). Sobre a relação entre saúde e valor, explica: "A palavra valere, que deu origem a valor, significa, em latim, passar bem. A saúde é uma maneira de abordar a existência com uma sensação não apenas de possuidor ou portador, mas também, se necessário, de criador de valor, de instaurador de normas vitais” (CANGUILHEM, 1990, p.163). Assim como Nietzsche, ele também concebe a saúde como o potencial do corpo em criar novas normas, tanto fisiológicas, quanto morais. Cf. CANGUILHEM, G. O normal e o patológico (Coleção Campo Teórico). (Trad: Maria Thereza R. de Carvalho Barrocas). $3^{a}$ edição. Rio de Janeiro, Forense Universitária, 1990.

${ }^{56}$ Oliveira, ao contrapor um dispositivo mecânico a um sistema complexo como um organismo vivo, explica que neste, a ação não se resume aos processos adaptativos, mas há também possibilidade de reorganização, criação de novas estruturas, sucessivas invenções: "os sistemas mecânicos simples são incapazes de transformar suas estruturas internas, suas composições, suas naturezas, em suma, para responder a novas demandas que surjam no meio, enquanto sistemas complexos como seres vivos podem adaptar-se, mudar sua natureza, para assimilar pressões do ambiente (...) Em vez do caráter perpetuamente repetitivo inerente à imagem-máquina, encontramos agora uma natureza inventiva, criadora, artista” (OLIVEIRA, 2003, p.149-150). Cf. OLIVEIRA, L. A. Biontes, bióides e borgues. In: O Homem-máquina: a ciência manipula o corpo. São Paulo, Companhia das Letras, 2003. 
se o filósofo alemão fala em “cura”, é precisamente desse potencial de reorganização e manutenção da luta, após uma desagregação dos arranjos de impulsos, que ele se refere.

Desta forma, vemos que a grande saúde não é o outro da doença, da décadence, pois é também por ela constituída. Como mobilização do corpo, até mesmo a doença pode servir de "estimulante” ao combate, ao tempo em que exige uma “contra-investida” dos impulsos. Por isso, Nietzsche diz que "há sabedoria nisso, sabedoria da vida, em receitar-se à saúde mesma somente em pequenas doses” (MAI/HHI, I, Prefácio, 4). Afinal, se o filósofo se considera dotado de grande saúde é porque constantemente transitou por estados múltiplos e contraditórios (Cf. JGB/BM, 200; MAI/HHI, Prefácio, 7), experimentou até mesmo a décadence, “o declínio vital”, sem permanecer nela. Por conseguinte, sendo a saúde concernente ao combate, ele acredita que "uma medicina e maneira de pensar tranqüilizante” (JGB/BM, 200) consegue propiciar apenas um tipo mais fraco, que aspira ao repouso. A partir dessas considerações, podemos questionar se uma medicina que procura aplacar a guerra que é o homem, opondo resistência à mobilização dos impulsos, “que lutam entre si e raramente se dão trégua” (JGB/BM, 200), instaurando a paz, um estado de não-beligerância, de “conservação” de uma só relação de mando e obediência, consegue promover uma grande saúde.

A nosso ver, não realizando uma "apologia da enfermidade”, Nietzsche entende ser a saúde o potencial de “reação" do corpo, em episódios de doença. No Crepúsculo dos Ídolos, expõe seu ponto de vista:

Este homem jovem empalidece e murcha precocemente. Seus amigos dizem: tal ou tal doença é a causa. Eu digo: o fato de ele ter adoecido, o fato de ele não ter se oposto à doença, foi justamente o efeito de uma vida empobrecida, de uma extenuação hereditária (GD/CI, Os quatro grandes erros, 2). 
Vemos assim que, para o filósofo, ser saudável não é somente não adoecer, mas conseguir fazer oposição à enfermidade. Em Ecce Homo, ao falar sobre as doenças que o acometeram, afirma que elas foram as conseqüências e não as causas de seu esgotamento geral. Sobre a sua doença dos olhos, às vezes aproximando-se da cegueira, era apenas decorrência e não causa de sua debilidade: "de modo que, com cada aumento de força vital, também a visão aumentou outra vez” (EH/EH, Por que sou tão sábio, 1).

Em vista disso, podemos presumir que se as práticas médicas continuamente impedirem o corpo de dar essas respostas, sobretudo através de recursos medicamentosos, o fragilizarão em suas estratégias de resistência ${ }^{57}$. Decerto, as medicações são úteis e necessárias, quando o corpo não tem como responder à enfermidade sem o auxílio delas. Mas, em nossa sociedade, fazemos um uso abusivo de remédios e, por imediatismo, sequer esperamos o tempo de resposta do corpo ao acometimento, enfraquecemos seu potencial de restabelecimento espontâneo. Procurando apenas atacar a doença e fazer cessar a dor, nos esquecemos de fortalecer a capacidade de resistência corporal, por exemplo, através de mudanças nos hábitos alimentares e nos ritmos de repouso e trabalho.

Em sua análise da décadence, Nietzsche explica que o desprazer é pernicioso, desaconselhável pelo instinto de autoconservação. Os décadents, ao darem ao prazer um valor supremo, cultuam um "hedonismo sobre bases inteiramente mórbidas” (AC/AC, 30).

\footnotetext{
${ }^{57}$ Por essa perspectiva, Samuel Hahnemann, na exposição da doutrina homeopática (1810), critica o método de tratamento alopático que oferece doses contínuas e excessivas de medicamentos para atacar a doença, acabando por fragilizar o doente. Ele acredita que as doenças provocam uma alteração da força vital, que precisa ser restabelecida por uma “doença medicinal”: “[a homeopatia] emprega para a cura apenas aqueles medicamentos cujo poder de modificar e desequilibrar (dinamicamente) a saúde ela conhece com exatidão, e escolhe um cujas forças modificantes (a doença medicinal) são capazes de remover a doença natural por semelhança (similia similibus), $e$ esse é administrado ao paciente em formas simples e em doses fracas (tão pequenas que, sem causas dor ou enfraquecimento, são, não obstante, suficientes para remover o mal natural): daí se conclui que sem enfraquecer, prejudicar ou torturar o doente, a doença natural é extinta, e o doente, já durante a convalescença, fortalece-se e assim fica curado" (HAHNEMANN, 1989, p.XXXV). Cf. HAHNEMANN, S. Organon da arte de curar (Trad: Eric Grüen). “Benoit Mure”. $4^{\mathrm{a}}$ edição. São Paulo, 1989.
} 
Por terem uma extrema suscetibilidade ao sofrimento, têm "medo da dor, mesmo do que é infinitamente pequeno na dor” (AC/AC, 30). Na Genealogia da Moral, o filósofo diz que o rebanho doente recorre a toda sorte de medicações ${ }^{58}$ que reduzem o "sentimento vital" ao nível mais baixo, para se livrar do "sentimento de obstrução fisiológica” (GM/GM, III, 17). Todavia, apesar das medicações que lança mão combaterem o desprazer, não atuam nas causas da doença: “o sentido dessa espécie de medicação não objetiva curar doenças, mas combater a depressão, diminuindo e amortecendo o seu desprazer” (GM/GM, III, 20). Por isso, Nietzsche coloca em questão se o sacerdote ascético é de fato um médico, visto que as medicações que administra apenas entorpecem, não agindo nas causas da doença (Cf. GM/GM, III, 17).

Isso nos leva a refletir se uma prática médica que apresenta como resposta a doença somente a medicação, sem investigar detidamente suas causas, promove um melhora efetiva da condição de quem recorre a ela. No mais das vezes, as causas da enfermidade residem nas condições insalubres de vida, nas péssimas condições de moradia e trabalho. Mas, pela facilidade de acesso a recursos medicamentosos, acabamos por recorrer a meios de analgesia, sem investigarmos com mais cautela as causas do desprazer. Sem combater as causas do mal-estar, o medicamento tem efeito efêmero e paliativo.

Mas, Nietzsche também diz que os diferentes arranjos de impulsos, que no decorrer da luta se efetivam, impõem múltiplas perspectivas, diferentes pontos de vista. Não obstante, isso não significa que o filósofo resvale em um “fisiologismo” limitado. Em

\footnotetext{
${ }^{58}$ Ao ver de Nietzsche, as medicações que os décadents costumam lançar mão para se livrarem da "depressão fisiológica” são a religião, a filantropia e a atividade maquinal. Ao tempo em que a medicação sacerdotal livra o homem da "depressão fisiológica” com a ajuda de seu sistema de entorpecimento, mitigador, narcotizante (Cf. GM/GM, III, 17) e a atividade filantrópica promove uma "pequena superioridade” àquele que ajuda em relação àquele que é beneficiado, de outro modo, através da "benção do trabalho": “O alívio consiste em que o interesse do sofredor é inteiramente desviado do sofrimento - em que a consciência é permanentemente tomada por um afazer seguido do outro, e em conseqüência resta pouco espaço para o sofrimento: pois ela é pequena, esta câmara da consciência humana” (GM/GM, III, 18).
} 
outros termos, ele não procura reduzir o psiquismo ao aparelho neuro-cerebral. Como vimos, ancorada em uma fisiopsicologia, entendida como multiplicidade de impulsos em luta, sua psicologia tem em vista que é do combate que emergem os pensamentos, e que mesmo o pensamento consciente é um impulso que “toma a palavra” (Cf. GM/GM, I, 2). Desta forma, não acreditando na possibilidade de separar a alma ou “espírito” do corpo, ele pode considerar os pensamentos sintomas da saúde ou doença corporal. Como psicólogo, detecta as "índoles de corpo" que se escondem por trás das filosofias (Cf. FW/GC, Prefácio, 2). Como genealogista, considerando que as diferenças valorativas indicam uma diversidade tipológica, passa a diagnosticar a grande saúde e a décadence através das “tábuas de valor” que os tipos advogam.

Em vista disso, se Nietzsche se considera um tipo saudável é porque adotou a óptica da décadence e experimentou a diferença perspectiva que a singulariza, mas não se ateve a ela (EH/EH, Por que sou tão sábio, 1). Com efeito, se, através de sua psicologia, ele mostra que é preciso ter uma grande saúde para experimentar muitos e opostos modos de pensar (Cf. MAI/HHI, Prefácio, 4), pelo prisma genealógico, esclarece que ela também diz respeito à revisão dos valores que sustentamos.

Na atualidade, quando pensamos que a saúde física não se separa da mental, pensamos na redução do psiquismo ao aparelho neuro-cerebral. Não obstante, vemos a insuficiência dessa visão no trato das chamadas doenças mentais, não sendo estas de todo redutíveis a alterações neurofisiológicas. Na maioria das vezes, o sofrimento mental está associado às relações conflitivas que o homem estabelece com o mundo. De fato, vemos que uma mudança no modo pelo qual o homem se relaciona com aqueles que o cercam em muito contribui para a superação de um momento de desagregação, de “crise”. 
A nosso ver, outra forma de redução do humano, que nos é contemporânea, é identificálo integralmente ao código genético ${ }^{59}$, acreditando que neste está inscrito todas as predisposições à enfermidade. É crendo nisso que, em busca do sucedâneo do “tipo ideal”, a ciência, através da biotecnologia, da decodificação do DNA humano e das técnicas de programação genética, aspira à produção de um exemplar saudável, não predisposto ao adoecimento, como se fosse possível eliminar o acaso da experiência humana ${ }^{60}$.

A partir disso, também podemos colocar em questão práticas médicas, pautadas em uma concepção de “saúde ideal”. Segundo Nietzsche, não há $a$ saúde, mas “mil saúdes” (ZA/Za, I, Da virtude que dá). Segundo ele, acreditar em uma saúde é crer na igualdade entre os tipos. Apostando na diversidade, o filósofo revela que a igualdade entre os homens advém da mentira cristã da igualdade das almas (Cf. AC/AC, 43). Por isso, defende que não há como alcançar um "ideal de homem”, assim como não há como estabelecer um “ideal de moralidade” ou um "ideal de felicidade” (Cf. GD/CI, Os quatro grandes erros, 8). Em vista disso, urge refletir se nossas práticas de saúde, ao advogarem a universalização de um tipo, juntamente a isso, realizam a imposição de uma dada moralidade e a padronização de critérios de felicidade.

${ }^{59}$ Frezzatti Jr. defende que fisiologia de Nietzsche, ao operar a superação da dualidade cultura e biologia, frustra as expectativas dos que acreditam que o genoma humano pode ser identificado à humanidade e que somos produtos da inscrição presente em nossos cromossomos, sendo os fatores externos apenas acidentais. Em seguida, esclarece: "Estes ainda acendem suas esperanças na antiga fogueira da metafísica dualista platônica, ou seja, enxergam o DNA como uma espécie de alma ou de forma (eidos) aristotélica que seria responsável pela verdadeira essência da natureza humana” (FREZZATTI Jr. 2006, p.300). Cf. FREZZATTI Jr. W. A. A fisiologia de Nietzsche: a superação da dualidade cultura/biologia (Coleção Nietzsche em Perspectiva). Ijuí, Ed. Unijuí, 2006.

${ }^{60}$ Kahn investiga, no contexto de uma discussão sobre a clonagem humana, as principais reações éticas ao uso de métodos de manipulação genética, que visam assegurar o nascimento de uma criança saudável, que não esteja propensa a desenvolver afecções ou envelhecer prematuramente. Ao refletir sobre os limites que devem ser impostos ao desejo dos pais de terem um filho "prédesenhado", conjetura: "A questão já aparece na escolha do sexo; poderia estender-se, no futuro, com o avanço dos conhecimentos em genética, a outros traços não patológicos, físicos ou mesmo psíquicos, dos filhos” (KAHN, 2003, p. 237). KAHN, A. Morte do sexo? In: O Homem-máquina: a ciência manipula o corpo. São Paulo, Companhia das Letras, 2003. 
Com efeito, entendemos que é por não acreditar na existência de um "tipo ideal", universal, abstrato, que Nietzsche pode desdobrá-lo em um quadro tipológico, conforme as possibilidades perspectivas de cada tipo ${ }^{61}$. Ele diz ver na efetividade uma exuberância de tipos e afirma ser uma ingenuidade dizer "assim-e-assim deveria ser o homem!” (GD/CI, Moral como contranatureza, 6). Além disso, atento à conotação moral que subjaz ao imperativo do tipo homem, universal, considera ridícula a atitude dos que dizem "Ecce Homo”, “assim e assim tu deverias ser!” (GD/CI, Moral como contranatureza, 6). Ao não querer impor sua "tábua de valores”, mas aventar a criação de uma multiplicidade delas, subintitula sua autobiografia, Ecce Homo, de como alguém se torna o que é (wie man wird, was man ist $)^{62}$. Ao contrário de um tipo fixado, o filósofo apresenta um tipo em trânsito, mutável, capaz de adotar diferentes perspectivas, diversos conjuntos valorativos. Portanto, é para se opor à universalidade do tipo homem que ele defende a singularidade tipológica e o caráter perspectivístico das estimativas de valor.

Ao nos levar a pensar a saúde de acordo com a singularidade tipológica, Nietzsche nos faz questionar o alcance de métodos e práticas médicas de pretensão universal. Decerto, as práticas universais conseguem obter boas respostas quando se direcionam para o que em nós é semelhante, mas, em grande medida, não conseguem alcançar o que em nós é singular. Isso porque operam a partir de um “corte transversal”, contemplando apenas o que é da ordem do genérico e passando ao largo do que em nós é único, ilimitadamente

\footnotetext{
${ }^{61}$ Caracterizada pelo perspectivismo, a efetividade é marcada pela diversidade, malgrado o homem alegar superioridade em relação às perspectivas não-humanas (Cf. FW/GC, V, 374). A nosso ver, é essa suposta superioridade que legitima os abusos cometidos no trato com animais, utilizados em experiências científicas. Nas palavras de Nietzsche, é o que justifica: "os sofrimentos de todos os animais até agora interrogados com o bisturi, para a obtenção de respostas científicas” (GM/GM, II, 7).

${ }^{62}$ Em caminho oposto ao de Descartes que, em seu relato autobiográfico no Discurso do Método e nas Meditações Metafísicas, apresenta o percurso de um "eu psicológico” a um "eu universal” e, após a prova da existência de Deus, a um “eu ontológico” (Cf. GUÉROULT, 1953, p.58), ao relatar suas experiências, Nietzsche não ultrapassa o terreno da singularidade. Sobre o percurso cartesiano Cf. GUÉROULT, M. Descartes selon l'ordre des raisons. Paris, Aubier Montaigne, 1953.
} 
individual $^{63}$. De outro modo, se quiserem propiciar uma "grande saúde", não podem ser um "leito de Procusto". Elas devem ser plásticas para dar conta da diversidade dos tipos humanos, respeitando a singularidade das fisiologias ${ }^{64}$ e o conjunto valorativo que lhes concerne.

Com efeito, as práticas de saúde devem ter em vista que se direcionam para diferentes configurações fisiopsicológicas. Se visarem à universalização de um tipo, à imposição de uma única perspectiva, de um mesmo conjunto valorativo, trabalharão na direção da conservação do mesmo, da “mesmicidade” (Ipsissimosität) e conseguirão promover apenas uma "pequena saúde”. Isso porque cada um de nós tem uma saúde diferente, um universo de potencialidades próprio a ser explorado, advogamos distintos valores, temos diferentes critérios de felicidade. Quando acreditamos na igualdade dos tipos, tentamos reproduzir uma mesma moral, um mesmo critério de felicidade, operamos uma generalização, perdemos de vista as diferenças, massificamos, arrebanhamos.

De acordo com Nietzsche, somente entre os membros de um rebanho, todos querem, sentem e pensam do mesmo modo: "Todos querem o mesmo, todos são iguais; e quem

\footnotetext{
${ }^{63}$ Argumentamos aqui fazendo uma analogia com a análise que Nietzsche faz do "corte transversal” operado pela consciência. Como vimos, para o filósofo, consciência e linguagem têm procedência comum no solo da gregariedade. Formadas para estabelecer uma ponte de comunicação entre os homens, carregam a marca do genérico e do superficial, do mediano e do inteligível a todos. Por isso, ele diz que a consciência faz parte no homem do que de natureza de comunidade e rebanho, pois só consegue transmitir o que é da ordem do gregário, passando ao largo do que em nós é singular (Cf. FW/GC, V, 354).

${ }^{64}$ Segundo Peralta, Nietzsche nos mostra que mais do que corpos, somos fisiologias singulares. Daí a necessidade de plasticidade nas práticas médicas: “A rica multiplicidade de respostas do 'corpo' põe em evidência a multiplicidade de fisiologias e, por sua vez, suas diferenças e particularidades. A fisiologia, longe de ser um campo do universal, é um campo do estritamente particular. Certamente, é possível enunciar princípios médicos, mas frente às fisiologias os princípios se alteram. Nietzsche insiste que não há fisiologias idênticas. As fisiologias individuais dentro de uma 'espécie' são semelhantes pela morfologia dos indivíduos; mas, sua morfologia comum os faz semelhantes e não idênticos” (PERALTA, R. 2001, p.42). Cf. PERALTA, S.E.R. Biología y lenguaje en Nietzsche. Rev. Filosofía Univ. Costa Rica, XXXIX (98), 41-46, Julio-Diciembre, 2001.
} 
sente de outro modo vai, voluntário, para o manicômio” (Za/ZA, O prólogo de Zaratustra, 5). Isso porque os homens necessitaram da perspectiva da consciência para se comunicar e criar regras de convívio para o grupo. Como estratégia de autoconservação, eles tiveram que se ater à consciência e à linguagem lógico-conceitual (FW/GC, V, 354; JGB/BM, 268). Para compor seu conjunto valorativo, passaram a identificar a racionalidade à virtude e à felicidade. A partir disso, desejando que todos tenham os mesmos critérios de felicidade e de moralidade, fazem com que toda perspectiva que escapa ao habitual, ao comum, seja banida para o locus do “problemático”, do exilado pela moral (Cf. EH/EH, Prólogo, 3).

Tendo em vista a crítica nietzschiana à tirania do impulso racional, podemos fazer algumas reflexões sobre a experiência da loucura. Podemos supor que o que chamamos loucura é a irrupção de outros impulsos, que não só o racional, que querem tomar precedência. A polifonia presente na loucura, as múltiplas vozes, os diferentes “Eus”, decorre da luta de diferentes impulsos que querem "tomar a palavra”. Assim, entendemos que, apesar do rompimento com a linguagem gregária, convencional, o discurso do louco tem algo a nos dizer ${ }^{65}$. Ele nos mostra que é possível, a partir da mobilização de outros impulsos, criarmos outros modos de subjetivação. Assim, vemos que a crítica ao sujeito moderno, a res cogitans cartesiana, abre a possibilidade de pensarmos em outras formas de subjetividade.

Ainda hoje, em nome da racionalidade, asilamos e medicamos a loucura sem compreender o sentido que essa irrupção de impulsos comporta. Alegando tratamento

\footnotetext{
${ }^{65}$ Nessa direção, Pelbart defende que, além da extinção dos manicômios, é necessário que nos libertemos do "manicômio mental”, através do reconhecimento da desrazão em nós: "Libertar o pensamento dessa racionalidade carcerária é uma tarefa tão urgente quanto libertar nossas sociedades dos manicômios. Isso significa que no plano de nossa geografia cultural e política é preciso recusar o Império da Razão. Talvez seja isso também que os loucos sempre quiseram nos dizer, e que nós ainda não conseguimos escutar” (PELBART, 1999, p.134). Cf. PELBART, P. P. Manicômio Mental: a outra face da clausura (SaúdeLoucura 2). Hucitec, 1999, p. 131-138.
} 
médico, procuramos a "racionalidade a qualquer preço" 66 e o enquadramento do louco num tipo socialmente aceito ${ }^{67}$. Acreditamos que não nos acercaremos do sofrimento que medeia a experiência da loucura através da internação asilar e do entorpecimento medicamentoso. O que queremos dizer com isso é que saúde não se produz em espaços de exclusão e que a medicação não é suficiente como resposta para uma demanda em saúde. Se a prática médica visar somente remitir os sintomas, através de medicamentos psicotrópicos, sem captar o sentido do sofrimento em cada experiência singular, podemos questionar se ela não está servindo maiormente como um meio de entorpecimento.

Nietzsche nos mostra que, para cada um, o sofrimento tem uma significação singular, possui sentido e valor próprios ${ }^{68}$. Nos décadents, o sofrimento desperta um "ódio instintivo contra a realidade" (AC/AC, 30) e, por isso, eles deslocam o "sentido da vida" para um além-mundo (Cf. AC/AC, 43). Diante do sofrimento, da velhice e da morte, passam a pregar os valores do ressentimento: "Se deparam com um enfermo ou um velho ou um

\footnotetext{
${ }^{66}$ No Crepúsculo dos Ídolos, Nietzsche diz que Sócrates, ao prescrever a "racionalidade a qualquer preço" como remédio contra a décadence, parecia um médico, um salvador, mas era somente um “mal-entendido” (Cf. GD/CI, O problema de Sócrates, 11).

${ }^{67}$ Foucault, na História da Loucura, diz que o que se chama de prática psiquiátrica é "uma certa tática moral, contemporânea do fim do século XVIII, conservada nos mitos da vida asilar e recoberta pelos mitos do positivismo" (FOUCAULT, 2004, p.501). Ao discorrer sobre o a prática do internamento, explica que no interior do asilo era essencial que a razão fosse significada por tipos sociais cristalizados. E ao reconhecer que o que constitui a cura do louco é sua estabilização num tipo social moralmente reconhecido e aprovado, conclui: "E é bem de mito que se deve falar quando se faz passar por natureza aquilo que é conceito, por liberação de uma verdade o que é reconstituição de uma moral, por cura espontânea da loucura aquilo que talvez não passe de sua secreta inserção numa realidade artificiosa” (FOUCAULT, 2004, p.476). Cf. FOUCAULT, M. História da Loucura na Idade Clássica (Trad: José Teixeira Coelho Netto). São Paulo, Perspectiva, $7^{\mathrm{a}}$ edição, 2004.

${ }^{68}$ Segundo Fink, Nietzsche lança um olhar agudo sobre as possibilidades criadoras que o sofrimento e certos estados de extrema fraqueza encerram, revelando a potência criativa e secretamente ambígua da doença: “A morbidezza pode conduzir a uma consciência mais intensa da existência, mas também a uma vingança contra a vida” (FINK, 1985, p.171). Cf. FINK, E. Nova experiência do mundo em Nietzsche In: MARTON, S. (Org). Nietzsche hoje? Colóquio de Cerisy (Trad: Milton Nascimento e Sônia Salzstein Goldberg). São Paulo, Brasiliense, 1985.
} 
cadáver, dizem logo: ‘A vida está confutada!’” (Za/ZA, Dos pregadores da morte). De outro modo, em seus escritos autobiográficos, o filósofo apresenta outra perspectiva sobre o sofrer. Ele diz que seus episódios de dor e enfermidade propiciaram uma completa revisão de valores e uma radical mudança de hábitos (Cf. MAI/HHI, Prefácio, 4; EH/EH, Por que sou tão sábio, 2).

Com efeito, no contexto dos prefácios de 1886, vemos a significação que Nietzsche dá à seus episódios de enfermidade. Para ele, ser saudável é poder fazer mesmo da doença um ensejo para adotar diferentes perspectivas, evitando o ressentimento ante o sofrimento que inevitavelmente dela advém. No prefácio ao segundo volume de Humano demasiado humano, conta que palmilhou todas as sendas abertas pelo sofrimento, sem com isso ressentir-se, tornar-se um pessimista, pois sempre esteve disposto a "defender a vida contra a dor e podar todas as conclusões que, da dor, da desilusão, do fastio, do isolamento e de outros terrenos pantanosos, costumam brotar, iguais a venenosas esponjas” (VM/OS, prefácio, 5). Nesses períodos, ele aprendeu a arte de falar como alguém que não sofre e passa privação, mantendo o equilíbrio, a disponibilidade e a gratidão para com a vida.

Em Ecce Homo, Nietzsche fala que seus momentos de "baixa vitalidade” não o tornaram um pessimista. Ao contrário disso, possibilitaram que as pequenas coisas cotidianas ganhassem outro matiz:

Assim, de fato, me parece agora aquele longo tempo de doença: descobri a vida como que de novo, inclusive a mim próprio, saboreei todas as boas e pequenas coisas, como não seria fácil a outros saboreá-las - fiz de minha vontade de saúde, de vida, minha filosofia... (EH/EH, Por que sou tão sábio, 2)

Depois de longo tempo, ao voltar-se para sua trajetória, o filósofo percebe que seus episódios de enfermidade possibilitaram a descoberta de um outro “si mesmo”. Com isso, 
ele nos mostra que é possível resignificar a própria vida, a cada momento em que nos voltamos para ela e recordamos o vivido.

Portanto, se os décadents atribuem a seus episódios de sofrimento um único sentido, Nietzsche consegue atribuir outros sentidos a seus episódios de enfermidade. A exemplo disso, em Ecce Homo, diz que sua doença dos olhos fez com que colocasse fim à "bibliofagia”, impedindo que lesse outros Eus:

A doença deu-me igualmente o direito a uma completa inversão de meus hábitos; ela permitiu, ela me ordenou esquecer; ela me presenteou com a obrigação à quietude, ao ócio, ao esperar e ser paciente... Mas isto significa pensar! (EH/EH, Humano demasiado humano, 4)

Apresentando uma significação singular a sua doença dos olhos, ele mostra a polissemia da ação humana. Em A Gaia Ciência, diz que somente uma ação mecânica encerraria um único sentido (Cf. FW/GC, V, 376). Ele acredita que a ação humana vista por um viés estritamente mecânico não seria contemplada em seu caráter polissêmico, estaria “carente” de sentido, desvalorizada. Assim, vemos que o gesto humano, por não ser mecânico, sempre vem acompanhado de um sentido, de uma significação, de uma valoração. Entendemos, assim, que se não somos um corpo-máquina, a ação do homem será sempre permeada por valores, não havendo uma separação entre o gesto e o sentido que ele encerra.

Nietzsche não apresenta apenas outra significação para a dor, mas também ao envelhecimento e à morte. A partir de sua filosofia, a morte pode ser vista como um processo no qual o conjunto de impulsos que compõe uma configuração fisiopsicológica se desagrega totalmente, passando a compor outras formas na efetividade: “'Agora morro e desapareço’, dirias, ‘e num instante não serei mais nada. As almas são tão mortais quanto os corpos” (Za/ZA, II, O convalescente, 2). Não obstante, enquanto configuração 
fisiopsicológica “consciente de si”, o homem sempre terá de se haver com a questão de seu envelhecimento e finitude.

Envelhecer, para o filósofo, parece significar uma mudança de perspectiva em relação à vida. Ele acredita que alguns envelhecem cedo demais, outros permanecem sempre jovens (Cf. ZA/Za, I, Da morte voluntária). No entanto, nós criamos estratégias para protelarmos o envelhecimento e nos recusamos a conviver com ele, através do asilamento dos idosos, ou tentamos mascará-lo, através de cirurgias estéticas. Devido às mudanças que acontecem no corpo, a diferença em relação à juventude cultuada em nossa sociedade, à sua aproximação ao momento morte, o envelhecimento é uma objeção. Não o entendemos como a entrada em outra fase da vida, como um outro olhar em relação à nossa própria trajetória.

No Crepúsculo dos Ídolos, no parágrafo intitulado “Moral para médicos”, em contraposição à “comédia deplorável e horripilante” na qual o cristianismo transformou o momento da morte, Nietzsche diz que se, alguns recusam a morte e, assim, querem prolongar a vida a todo custo, mesmo que um "prosseguir vegetando na dependência covarde de métodos e práticas, depois que o sentido da vida, o direito à vida se dissipou” (GD/CI, Incursões de um Extemporâneo, 36), outros, querem que aconteça no "tempo certo”, em meio a crianças e a testemunhas, quando uma despedida ainda é possível. Querem ter o direito de morrer de maneira orgulhosa, quando a possibilidade de viver de maneira orgulhosa se esvaiu.

Na mesma direção, em Assim falava Zaratustra, o filósofo diz que a morte no “tempo certo” somente é possível àquele que completou sua tarefa e que pode deixar os frutos de sua realização como herança aos outros. Assim, para aprender a morrer é necessário primeiro aprender a viver: “quem nunca vive a tempo, como iria morrer a tempo?” (Za/ZA, I, Da Morte Voluntária). Por isso, critica os homens que, como maçãs podres e bichadas, por covardia, se mantêm pendurados nos galhos da árvore da vida. De 
outro modo, o "homem maduro", aquele que entende melhor da vida e da morte, quer morrer no "tempo certo”, por anseio de retorno à terra: “assim quero eu mesmo morrer, para que, meus amigos, por amor meu, ameis mais a terra: e à terra quero voltar, para ter paz naquela que me gerou” (Za/ZA, I, Da morte Voluntária). Assim, sob o lema "Morre a tempo!”, Zaratustra aventa a necessidade de outro “aprendizado” sobre a morte: “Essa difícil arte de, a tempo, - ir-se embora” (Za/ZA, I, Da Morte Voluntária).

Mas, se, no Crepúsculo dos Ídolos, o filósofo nos coloca a questão de até quando devemos submeter um enfermo a meios artificiais de manutenção da vida, máquinas e fármacos ${ }^{69}$, em Assim falava Zaratustra, ele faz com que pensemos na qualidade de vida que levamos. Advertindo sobre o risco que corremos de passar a vida temendo a morte, o filósofo nos alerta sobre a maior importância de ter uma meta e de se realizar na concretização dessa tarefa. Além disso, nos faz pensar sobre a qualidade de vida que a sociedade atual oferece a seus membros, reduzindo à vida de muitos à mera sobrevivência $^{70}$.

${ }^{69}$ Gadamer, por influência da medicina antropológica da Escola de Heidelberg, em especial, dos trabalhos de Viktor von Weizsäcker, diz que vivemos um processo de "desmitologização da morte": "o prolongamento da vida acaba por ser um prolongamento da agonia e um ofuscamento da experiência do eu; e culmina no desaparecimento da experiência da morte. A atual química dos anestésicos tira toda sensação à pessoa que sofre, ao mesmo tempo que a manutenção artificial das funções vegetativas do organismo transforma o homem numa peça de um processo mecânico." (GADAMER, 1997, p.66). Cf. GADAMER, H-G. O mistério da saúde: o cuidado da saúde e a arte da medicina. Lisboa, Edições 70, 1997.

${ }^{70}$ Marton lança mão dos pressupostos da filosofia nietzschiana para refletir sobre o problema da eutanásia. Deslocando a questão para o problema da qualidade de vida que a sociedade possibilita a seus membros, coloca em cena aspectos culturais, sociais, políticos e econômicos. Entendendo ser o prolongamento da vida "a todo custo" um procedimento inútil e doloroso, pondera: "Mas por que não perseguir a utopia de que, numa outra sociedade, todo ser humano teria assegurado o seu direito a uma morte digna porque veria antes respeitado o seu direito a uma vida digna. Então, aceitando a condição humana em sua fragilidade e finitude, não mais pensaria em vida e morte como termos excludentes. E, nesse quadro, a questão da eutanásia talvez não se colocasse mais em primeiro plano nos debates de bioética” (MARTON, 2002, 134). Cf. MARTON, S. Uma questão de vida e morte: a filosofia de Nietzsche e o problema da eutanásia. Rev. Hypnos. São Paulo. Ano 07/ nº 09, $2^{\circ}$ semestre/2002. p.120-134. 
Além de Nietzsche nos fazer ver que a vida não se opõe à morte, pois o conjunto dos impulsos que compõe uma configuração fisiopsicológica, mesmo depois de disperso, permanecerá na efetividade, esclarece que, em uma mesma configuração fisiopsicológica, a todo o momento, as ordenações hierárquicas de impulsos se desarranjam e se recompõem, sem que haja a desagregação completa do conjunto. Assim, também revela que experimentamos pequenas mortes cotidianas, nas quais constantemente nos despedimos de nós mesmos. Através disso, alude a um processo no qual o homem se faz diferente, se renova, em relação a si mesmo:

Solitário, percorres o caminho no rumo de ti mesmo! E teu caminho passa por ti mesmo e pelos teus sete demônios. Herege, serás para ti mesmo, e feiticeiro e vidente e doido e céptico e ímpio e celerado. Arder nas tuas próprias chamas, deverás querer; como pretenderias renovar-te, se antes não te tornasses cinza! (ZA/Za, I, Do caminho do criador).

Nietzsche nos ensina que podemos alterar nossas perspectivas, querer, sentir e pensar de outro modo, constantemente nos renovarmos. Mas, para tanto, diz que serão necessárias inumeráveis mortes, sofrimentos e transformações ${ }^{71}$. Afinal, nesse processo de modelagem de si, de recriação constante, muito de nós irá permanecer, muito será descartado. Em Para Além de Bem e Mal, o filósofo diz no homem, criador e criatura estão unificados: "no homem há matéria, fragmento, excedente, argila, lodo, insensatez, caos: mas no homem há também criador, formador, dureza de martelo, divindade de espectador e sétimo dia (...)”

${ }^{71}$ Para Nietzsche, criar é a "grande redenção" do sofrimento, o que torna a vida mais leve: "Sim, muitas mortes amargas deverá haver em vossa vida, ó criadores! Assim sereis intercessores e justificadores de toda transitoriedade. Se o criador quer ser ele mesmo a criatura, o recém-nascido, então, deve querer, também, ser a parturiente e a dor da parturiente. Em verdade, percorri meu caminho através de cem almas e cem berços e cem dores do parto. Já me despedi mais de uma vez e conheço as lancinantes horas derradeiras. Mas, assim quer a minha vontade criadora, o meu destino. Ou, para falar-vos mais honestamente: tal destino, justamente - é o que quer a minha vontade” (ZA/Za. II, Nas Ilhas bem-aventuradas). 
(JGB/BM, 225). Desta forma, ele resgata ao homem o papel de criador, fazendo com que agora ele se perceba uma obra de suas próprias mãos.

A partir disso, pela óptica nietzschiana, vemos que as práticas médicas devem propiciar que aquele que recorre a ela seja ativo, criativo, visto ser saudável não significa enquadrar-se em uma norma, mas poder ensaiar, transitar por processos de desagregação, de crise, experimentar outros modos de querer, sentir e pensar, criar diferentes sentidos à própria existência, rever valores e se preciso alterar modos de vida. Pelo mesmo viés, ser doentio é não ensaiar, é ater-se a uma só perspectiva, é estar impedido e travado na criação (Cf. FW/GC, V, 369). Estar enfraquecido é acreditar que todos os caminhos já são conhecidos e que, por isso, não há porque avançar: "É sempre assim o modo dos homens fracos, eles se perdem em seus caminhos. E por fim, pergunta ainda seu cansaço: Para que seguimos caminhos! Tudo é igual!” (ZA/ZA, Das velhas e novas tábuas, 16). De outro modo, Nietzsche nos mostra que nossa própria trajetória precisa ser criada, não de antemão, porque no mundo efetivo está esgotada toda previsibilidade, mas no próprio ato de caminhar:

E sempre e somente a contragosto perguntei pelos caminhos - isso sempre me repugnava! Preferia interrogar e experimentar os próprios caminhos. Experimentar e Interrogar - consistiu nisso todo o meu caminho (...). “Este, agora - é o meu caminho, onde está o vosso?” - assim respondia eu aos que me perguntavam “o caminho”. Por que o caminho - não existe! (Za/ZA, III, Da virtude que dá)

Quando Nietzsche apresenta sua trajetória filosófico-vivencial, mostrando que é possível percorrer outras veredas, quer contribuir para a elevação do homem no futuro, torná-lo mais saudável porque mais criativo. Ele acredita que temos potencial para sermos diferentes e alterarmos o que está a nossa volta. Isso porque quando criamos outros caminhos, por não 
estarmos separados do mundo, o mudamos também. Nós alteramos o mundo e somos moldados por ele. Toda mudança que nele ocorre repercute em nós, fazendo com que nosso “bem-estar” dependa da condição na qual ele se encontra. Isso faz com que a medicina, ao procurar tornar os homens mais saudáveis, também deva estar compromissada com a criação de um mundo melhor. 


\section{CONCLUSÃO:}

Indulgente é Zaratustra com os enfermos. Na verdade, não verbera os modos de seu consolo e ingratidão. Possam eles sarar e superar a si mesmos e criar para si um corpo superior ao que têm! (ZA/Za. I, Dos Ultramundanos)

Em nosso percurso, partimos da afirmação de que Nietzsche, diferentemente de toda uma tradição de pensamento que privilegiou o espírito, se empenhou em mostrar que é do corpo que provém todo sentido e valor. A tradição metafísica, da qual tomamos Descartes por emblemático, defende que o espírito é criação divina e que os sentidos e valores são

oferecidos por um além-mundo. A partir disso, o homem se orienta por valores transcendentes e coloca o sentido da vida em uma “outra vida”, após a morte. De outro modo, o filósofo alemão não separa o corpo da alma e os apresenta como uma multiplicidade de impulsos em luta. Esclarece também que o mundo efetivo é dessa mesma tessitura. Assim, se a tradição metafísica apresentou um corpo separado do espírito, um homem separado do mundo, Nietzsche ri da idéia de homem e mundo colocados lado a lado, “separados pela sublime pretensão da palavrinha 'e’” (FW/GC, V, 346). A seu ver, o homem é uma configuração fisiopsicológica, que está “mergulhada” na efetividade (Cf. GM/GM, II, 24). Portanto, não havendo "outro mundo", Nietzsche diz que é o homem mesmo que põe sentido e valor no mundo do qual integralmente faz parte, o efetivo. Mas, como a efetividade é caracterizada pela fluidez de forma e sentido (Cf. GM/GM, II, 12), os tipos humanos são diversos e os sentidos e valores que engendram também.

Vimos também que, para Nietzsche, a saúde ou doença dos tipos concerne à forma como se dá a luta de impulsos, em seus processos de ordenação e desagregação hierárquicas. Pelo seu viés, um tipo é dotado de grande saúde quando é caracterizado por constantes processos de rearranjo dos impulsos. Já um tipo décadent é caracterizado por um 
processo de anarquização de impulsos, no qual, por estratégia de autoconservação, um beligerante "tirano” toma a precedência e arrefece a luta. Ao ver do filósofo, cada vez que se efetiva uma diferente ordenação hierárquica, o tipo experimenta algo novo, outra perspectiva, outro ponto de vista. Assim, ser saudável é poder ensaiar, se reorganizar de outro modo, experimentar outras formas de querer, sentir e pensar, é não se aferrar ao já instituído, ao habitual, é poder criar sentidos e valores outros e a partir deles alterar modos de vida. De acordo com esses critérios, em sua autodiagnose tipológica, o filósofo se considera uma “índole bem lograda” (CF. EH/EH, Por que sou tão sábio, 2), malgrado seus constantes episódios de enfermidade. Isso porque ele conseguiu adotar larga gama perspectiva, experimentou até mesmo a estreita perspectiva do “declínio vital”, mas não se ateve a ela.

Ademais, no contexto genealógico, Nietzsche mostra que os homens passaram a desprezar o corpo e a caluniar a efetividade quando se viram diante da "ausência de sentido do sofrer” (Cf. GM/GM, III, 28). Encontrando como expediente a "rebelião contra os mais fundamentais pressupostos da vida”, eles passaram a ter um sofrimento ainda mais profundo, pois tiveram que solapar muitas de suas potencialidades, vê-las com maus olhos (Cf. GM/GM, II, 24). De outro modo, em seus escritos de caráter retrospectivo, o filósofo relata que apesar de ter sofrido, não objetou os processos efetivos. Fez de suas vivências dolorosas oportunidade para criação de valores afirmativos. Em suma, imprimiu a seu sofrimento outra significação. Acreditando que mesmo o sofrimento pode estar a serviço da criação de valores afirmativos do corpo e da efetividade, assevera: "para que haja o eterno prazer de criar (...) é preciso também que haja eternamente o ‘tormento da parturiente’...” (GD/CI, O que devo aos antigos, 4). Com efeito, foi em seus momentos de maior sofrimento que aprendeu a arte de não deixar que de sua dor nascesse o pior dos males, o ressentimento. 
Por fim, defendemos que as concepções nietzschianas de corpo e grande saúde possibilitam uma revisão dos pressupostos que orientam nossas práticas médicas. Ao apresentar a grande saúde, não como a ausência de enfermidade, mas como possibilidade de efetivar processos criativos, Nietzsche nos fez pôr em questão nossa concepção de saúde, entendida por oposição à doença. Isso não significa dizer que o filósofo faça uma “apologia da enfermidade”. Apenas considera que o adoecimento e a dor que daí costuma advir sempre fizeram e farão parte da experiência humana. Ele relata que sofreu dores terríveis e passou por muitos estados de doença, conseguindo se curar por ser "sadio no fundamento” (EH/EH, Por que sou tão sábio, 2). Sintoma de sua grande saúde, ele sempre escolheu os "remédios certos", esteve atento ao que lhe fazia bem, livros, companhias, lugares de morada. Respeitou seu "metabolismo", procurando digerir com facilidade alimentos e vivências. Não perseverou no que não podia em curto prazo mudar. Deu tempo ao tempo. Por isso, Nietzsche diz que sempre, mesmo doente, nunca foi um décadent, um tipo “mórbido”. Por esse viés, concluímos que saúde é, sobretudo, a “resposta” que o corpo é capaz de dar à enfermidade. Por isso, urge fortalecê-lo. Não obstante, diagnosticamos que nossas práticas médicas, centradas no ataque à doença e na rápida cessação da dor, rapidamente lançam mão de recursos medicamentosos. Relegando a segundo plano as relações do corpo com as “disposições fundamentais da própria vida” (EH/EH, Por que sou tão esperto, 10), muitas das vezes elas deixam escapar as reais causas da enfermidade. Quando isso ocorre, a medicação, importante recurso no processo de cura, acaba por ter efeito efêmero e paliativo.

A filosofia de Nietzsche também nos fez questionar nossos parâmetros de "bemestar” físico, mental e social. Saúde é uma forma de estar no mundo, a partir de um "bemestar” que não pode ser universalizado. Para o filósofo, um homem “bem constituído” é feliz a seu modo (Cf. GD/CI, Os quatro grandes erros, 2). Enquanto os décadents acham que todos devem ter os mesmos critérios de felicidade, advogar os mesmos valores e 
orientar os modos de vida de modo parecido, o filósofo acredita que os tipos são singulares, apresentam diferentes formas de criar sentidos, valores e orientar os modos de vida. Destarte, concluímos que através das práticas médicas, não há como propiciar $a$ saúde através de "padronizações” dietéticas, estéticas, éticas por que os tipos são diversos e as saúdes também. Atribuímos diferente significação à dor, ao envelhecimento e à nossa finitude. Vimos que, para o filósofo, a dor pode levar à criação de outros valores e à alteração nos modos de vida, o envelhecimento é uma perspectiva sobre a nossa própria trajetória, e somente quem não tem uma meta, uma tarefa, quem não se sente partícipe deste mundo e do que virá, teme a morte. Ademais, vivemos em desiguais condições, moramos, nos alimentamos e também nos relacionamos de modo distinto. Por isso, ressaltamos que a promoção à saúde também envolve aspectos políticos, educacionais e sociais, concernindo, sobretudo à qualidade de vida que nossa sociedade oferece a seus membros.

Nietzsche também nos diz que constantemente o homem morre e renasce de suas próprias cinzas. Ele dá nova significação a sua trajetória, altera os seus valores, reorienta seus modos de vida e constrói seu caminho a cada passo. Com isso, o filósofo nos ensina que o homem é criação de si mesmo e não criação divina, e que é nesse mundo que ele se molda, pelas suas próprias mãos. Mostrando que os males dos quais padecemos são o sofrimento com nós mesmos e com a péssima qualidade de vida no mundo, nos alerta que temos um compromisso com a nossa superação e com a melhoria deste mundo que nós mesmos criamos. 


\section{BIBLIOGRAFIA:}

Obras de Nietzsche:

A Gaia Ciência (trad. Paulo César de Souza). São Paulo, Companhia das

Letras, 2001

Além do Bem e do Mal (trad. Paulo César de Souza). São Paulo, Companhia das Letras, 2000.

Ecce Homo (trad. Paulo César de Souza). São Paulo, Companhia das

Letras, 2000.

El Anticristo (trad: Andrés Sánchez Pascual). Madrid, Alianza Editorial, 1974.

Genealogia da Moral (trad. Paulo César de Souza). São Paulo, Companhia das Letras, 1999.

Obras Incompletas (Trad: Rubens Rodrigues Torres Filho). OS PENSADORES. São Paulo, Ed. Nova Cultural, 1999.

NIETZSCHE, F. Sämtliche Werke. Kritische Studienausgabe, Berlim. Walter de Gruyter \& Co. 1967/1978. (organizada por Giorgio Colli e Mazzino Montinari)

\section{Outras obras:}

ANDLER, C. Nietzsche: sa vie et sa pensée. Paris, Gallimard, 4 ed. V.2. 1958.

ASSOUN, P-L. Freud et Nietzsche. Paris, Presses Universitaires de France , 1980.

BLONDEL, É. Nietzsche, le corps et la culture: la philosophie comme généalogie philologique. Philosophie d'aujourd' hui, Presses Universitaires de France, 1986. 
Nietzsche: a vida e metáfora (Trad: Fernando de Moraes Barros). Cadernos Nietzsche, São Paulo, Discurso Editorial, 16 (2004). p.07-51.

CANGUILHEM, G. O normal e o patológico (Coleção Campo Teórico). (Trad: Maria Thereza R. de Carvalho Barrocas). 3ª edição. Rio de Janeiro, Forense Universitária, 1990.

DELEUZE, G. Nietzsche et la Philosophie. Paris, Presses Universitaires de France, 1970.

DESCARTES. Obras Incompletas (Trad: J. Guinsburg e Bento Prado Júnior). OS PENSADORES. São Paulo, Victor Civita, 1973.

Princípios da Filosofia.[edição bilíngüe latim/português] (Trad: Guido Antônio de Almeida, Raul Landim Filho, Ethel M. Rocha, Marcos Gleizer e Ulysses Pinheiro). Rio de Janeiro. Ed. UFRJ, 2002.

FINK, E. Nova experiência do mundo em Nietzsche In: MARTON, S. (Org). Nietzsche hoje? Colóquio de Cerisy (Trad: Milton Nascimento e Sônia Salzstein Goldberg). São Paulo, Brasiliense, 1985.

FOUCAULT, M. História da Loucura na Idade Clássica (Trad: José Teixeira Coelho Netto). São Paulo, Perspectiva, $7^{\mathrm{a}}$ edição, 2004.

Nietzsche, a genealogia e a história In: Microfísica do poder (Trad: Roberto Machado). Rio de Janeiro, Edições Graal, 1979.

FREZZATTI Jr. W. A. A fisiologia de Nietzsche: a superação da dualidade cultura/biologia (Coleção Nietzsche em Perspectiva). Ijuí, Ed. Unijuí, 2006.

GADAMER, H-G. O mistério da saúde: o cuidado da saúde e a arte da medicina. Lisboa, Edições 70, 1997. 
GIACÓIA Jr., O. Nietzsche como psicólogo (Coleção Focus 6). Unisinos, 2001.

GUÉROULT, M. Descartes selon l'ordre des raisons. Paris, Aubier Montaigne, 1953.

HAAZ, I. Nietzsche, Ribot et les conditions biologiques de l'esprit. Collection Epistémologie et Philosophie des Sciences, l’Harmattan, 2002.

HAHNEMANN, S. Organon da arte de curar (Trad: Eric Grüen). "Benoit Mure”. $4^{a}$ edição. São Paulo, 1989.

MARQUES, J. Descartes e sua concepção de homem [com uma tradução do Tratado do Homem]. São Paulo, Edições Loyola, 1993 (Coleção Filosofia; v.25).

MARTON, S. Extravagâncias: ensaios sobre a filosofia de Nietzsche (Coleção Sendas e Veredas). Discurso Editorial / Editora UNIJUÍ, 2ª edição. 2001.

Uma questão de vida e morte: A filosofia de Nietzsche e o problema da eutanásia. Rev. Hypnos. São Paulo. Ano 07/ nº 09, 2º semestre/2002. p.120-134.

MÜLLER-LAUTER, W. A Doutrina da Vontade de Poder em Nietzsche (Trad. Oswaldo Giacóia Júnior). São Paulo, Annablume, 1997.

Décadence artística enquanto décadence fisiológica: a propósito da crítica tardia de Friedrich Nietzsche a Richard Wagner (Trad: Scarlett Marton). Cadernos Nietzsche 06, São Paulo, 1999. p.11-30.

OLIVEIRA, L. A. Biontes, bióides e borgues. In: O Homem-máquina: a ciência manipula o corpo. São Paulo, Companhia das Letras, 2003. 
PELBART, P. P. Manicômio Mental: a outra face da clausura (SaúdeLoucura 2). Hucitec, 1999, p. 131-138.

PERALTA, S.E.R. Biología y lenguaje en Nietzsche. Rev. Filosofía Univ. Costa Rica, XXXIX (98), 41-46, Julio-Diciembre, 2001.

POLITZER, G. Crítica dos Fundamentos da psicologia: a psicologia e a psicanálise (Trad: Marcos Marcionilo e Yvone Maria de Campos Teixeira da Silva). Editora UNIMEP, 1998.

SANTIAGO GUERVÓS, L.E. Nos limites da linguagem: Nietzsche e a expressão vital da dança (Trad: Alexandre Filordi de Carvalho). Cadernos Nietzsche 14, São Paulo, 2003. p.83-30.

TEIXEIRA, L. Ensaio sobre a moral de Descartes. $2^{\mathrm{a}}$ ed. São Paulo, Brasiliense \& Secretaria de Estado da Cultura, 1990. 